1991

\title{
The Bangladesh Women's Health Coalition
}

Bonnie J. Kay

Adrienne Germain

Maggie Bangser

Follow this and additional works at: https://knowledgecommons.popcouncil.org/departments_sbsr-pgy

Part of the Family, Life Course, and Society Commons, International Public Health Commons, Maternal and Child Health Commons, Public Health Education and Promotion Commons, and the Women's Health Commons How does access to this work benefit you? Let us know!

\section{Recommended Citation}

Kay, Bonnie J., Adrienne Germain, and Maggie Bangser. 1991. "The Bangladesh Women's Health Coalition," Quality/Calidad/Qualité no. 3. New York: Population Council. 
Quality/Calidad/Qualité, a publication of the Population Council, highlights examples of family planning and reproductive health programs that are providing unusually high quality care. This series is part of the Council's Robert H. Ebert Program on Critical Issues in Reproductive Health and Population, which, through scientific and practical efforts, seeks to improve and expand the scope and quality of reproductive health care. The philosophical foundation of the program, and of this series, is that women and their partners have a fundamental right to respectful treatment, information, choice, and follow-up from reproductive health care providers. The pamphlets reflect one of the four main thrusts of the program: enhancing the quality of family planning programs.

Projects are selected for documentation in the Quality/Calidad/Qualité series by an Advisory Committee made up of individuals who have a broad range of experience within the field of reproductive health and are committed to improving the quality of services. These projects are making important strides in one or more of the following ways: broadening the choice of contraceptive methods and technologies available; providing the information clients need to make informed choices and better manage their own health care; strengthening the quality of client/provider interaction and encouraging continued contact between providers and clients; making innovative efforts to increase the management capacity and broaden the skills of service providers at all levels; expanding the constellation of services and information provided beyond those conventionally defined as "family planning;" and reaching underserved and disadvantaged groups with reproductive health care services.

None of the projects documented in the series is being offered as a model for replication. Rather, each is presented as an unusually creative example of values, objectives and implementation. These are "learning experiences" that demonstrate the self-critical attitude required to anticipate clients' needs and find affordable means to meet them. This reflective posture is exemplified by a willingness to respond to changes in clients' needs as well as to the broader social and economic transformations affecting societies. Documenting the critical choices these programs have made should help to reinforce, in practical terms, the belief that an individual's satisfaction with reproductive health care services is strongly related to the achievement of broader health and population goals.

Publication of this edition of Quality/ Calidad/Qualité is made possible by support provided by the Ford Foundation, the Rockefeller Foundation, and the United Nations Population Fund (UNFPA).
Statements made and views expressed in this publication are solely the responsibility of the authors and not of any organization providing support for Quality/ Calidad/Qualité.

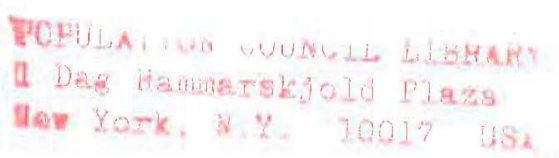

Number Three $1991 \quad$ ISSN 0-87834-057-2 Copyright (C) The Population Council 1991 


\title{
The Bangladesh Women's Health Coalition
}

\author{
by Bonnie J. Kay, Adrienne Germain, and Maggie Bangser
}

\begin{abstract}
Introduction
I'd heard about family planning before, but not this way. This is the only clinic where I was asked to sit down and where I was treated as an equal. If I knew about it this way, do you think I'd have six children?

Client, $B W H C$
\end{abstract}

Is a flexible, woman-centered reproductive health program responsive to women's needs an unobtainable luxury? Are the standards of quality care that this implies simply too high for most programs in developing countries to achieve? Does offering quality care mean that fewer clients can be served, or that the cost per acceptor will be prohibitively high?

In recent years, the idea of promoting woman-centered reproductive health services that emphasize quality of service delivery over quantity of contraceptive acceptors has been gaining wide currency among researchers, practitioners, women's health advocates and donor agencies. Of course, quality means different things to different people for the concept is a culturally and even personally relative one. Yet despite a diversity of views, some common themes have begun to emerge about what constitutes high quality reproductive health care for women. These include building a relationship of trust between provider and client, encouraging continuity of care, respecting the client's individual wishes and concerns, offering a range of fertility regulating methods and the information necessary to make informed choices, providing a constellation of additional services that respond to women's broader reproductive health needs and ensuring that these programs meet accepted standards of technical competence. While these elements may seem obvious, it is surprising how rarely they have been incorporated en bloc into most family planning services. Indeed, to some administrators they represent a wish list of luxuries that cannot possibly be attained in the resource-poor context of most developing countries.

The new emphasis on quality of care has come in large part from a dissatisfaction with the performance of many traditionally structured family planning clinics. Dissatisfaction stems in part from an inadequate choice of contraceptive methods, inconvenient service hours, long waits, insufficient privacy for clients during interview and examinations and care-givers who at times appear to be indifferent to clients' needs. For women unfamiliar with medical apparatus and routines, visiting such clinics can be a difficult or unpleasant experience. In addition, some family planning programs have been preoccupied with achieving a target number of acceptors in order to meet the expectations of their own bureaucracies, national programs or donor agencies. 


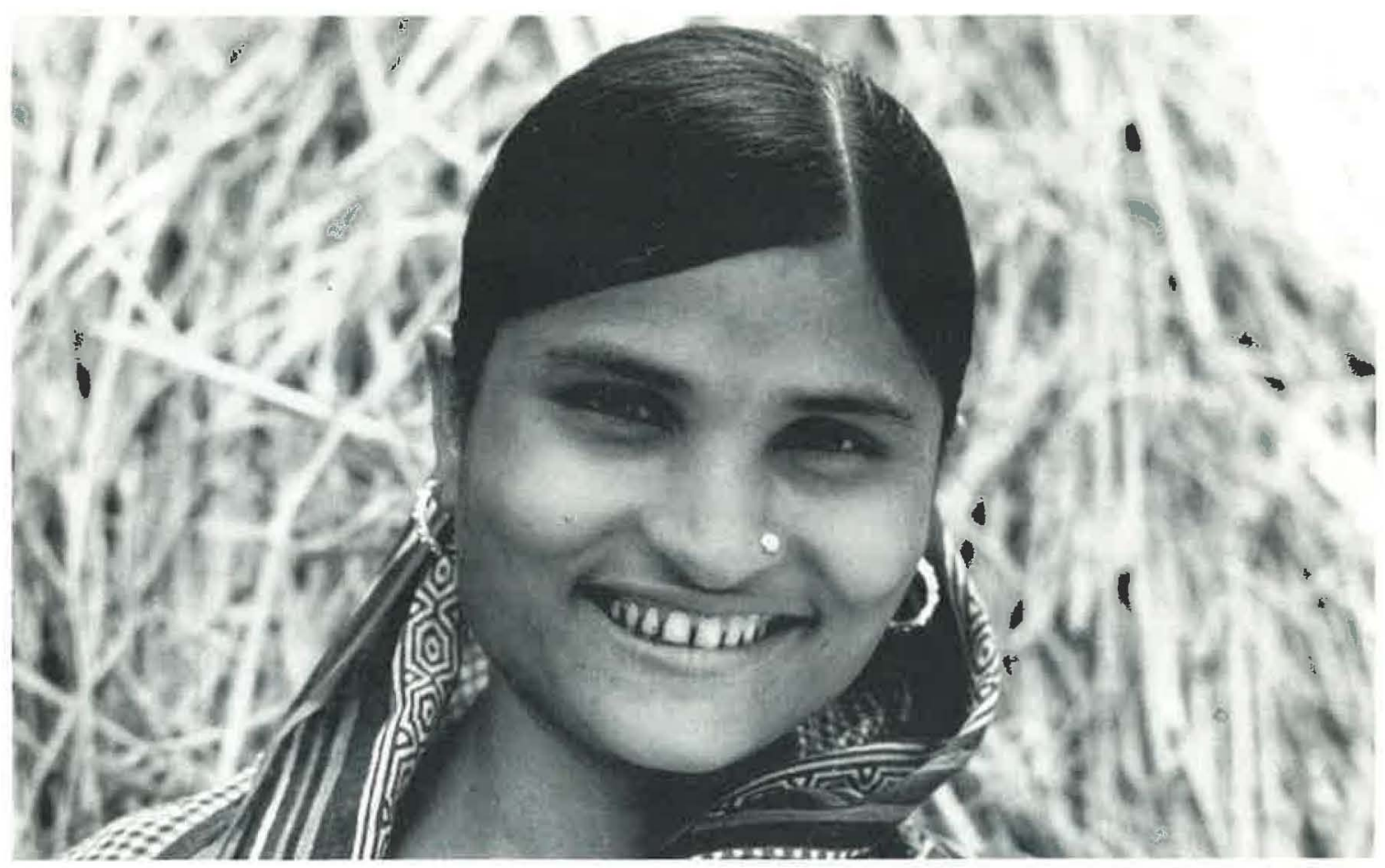

The Bangladesh Women's Health Coalition (BWHC) represents an important initiative in the movement toward more responsive modes of family planning delivery. Although it is conventional in its reliance on the model of the free-standing health clinic, BWHC is unconventional in its philosophy, spirit and commitment to serving women in need. BWHC clinics are welcoming places where clients feel comfortable, respected and understood. There is an emphasis on informed choice among a wide array of birth control methods, including early termination of unwanted pregnancy. BWHC clinics are also unusual in that family planning is not segregated from women's other health needs and those of their children. Primary health services, such as treatment of gynecological problems and early childhood diseases, are provided in the same setting; and all this is accomplished while maintaining a high level of cost-effectiveness.

In the context of a society where there are strict limits on the social role and physical mobility of most girls and women, BWHC has set itself the ambitious goal of enabling women-no matter what their income or education - to learn how to manage their own reproductive health and the health of their children in a way that enhances their sense of strength and competence.

The authors wish to acknowledge and thank Sandra Kabir, Executive Director of BWHC, for her assistance and patience in providing information, answering questions and checking for accuracy. 


\section{Background}

For most of the 45 million girls and women who live in rural Bangladesh, life has been the same for generations-a struggle to survive in the face of unrelenting poverty. A work day of 14 to 16 hours is not uncommon for, in addition to caring for her children, husband and in-laws, a woman often takes on other work, such as processing rice in a neighbor's house, to earn much needed money. Young girls are usually occupied in caring for younger siblings and managing the house, and have no time to go to school.

When a girl reaches puberty, custom demands that her family protect her from all encounters with men who are not members of her own family. Early marriage is the norm, but potential in-laws often demand a large dowryclothing, a watch and a transistor radio-which can cost as much as a family earns in three months. Social pressures force most women in Bangladesh to have many children quickly, especially sons; yet girls and women rarely have access to modern health care because services are unavailable or too expensive. This situation is aggravated by the fact that most doctors are men and it is usually unacceptable for women to be examined by a male doctor except in a dire emergency, and by then it is often too late.

About three million Bangladeshi women of reproductive age live in urban areas. Increasingly, poor rural families send their daughters to work in the homes of relatives or wealthier people in towns and cities. Rural women who have been widowed or divorced-approximately ten percent of women aged 25 to 49 -also move to urban areas to try to earn a living. For most of them, life is hard. They live in slums and work at whatever they can find. Some prepare food for lunch boxes which their sons deliver to factory and office workers. Many work as servants, earning only food and a place to sleep. If they become pregnant, they will be fired. Other young and mostly unmarried women work in modern industries such as garment factories, bakeries or pharmaceutical plants. They too will be fired if they become pregnant. Away from the protection of their families, some inevitably $d o$, and they and their children become outcasts. Hardly any services exist to help them.

Among better off, urban families, many young brides and mothers remain in traditional seclusion, only leaving their homes covered from head to foot in a burkah, or veil, and accompanied by a husband, mother-in-law or other responsible family member. Opportunities are, however, increasing for the daughters of some middle class urban families. With a high school or a university education, they can become government health and family planning workers, and teachers. However, as with poorer women, their future depends on being able to control their childbearing safely and effectively.

Although the lives and opportunities of Bangladeshi girls and women differ tremendously, they all have a common need for reproductive health services. At any one time, approximately five million women in Bangladesh are pregnant, 13 million are at risk of becoming pregnant and, of these, no more than 25 to 30 percent use modern contraception.

Since 1971, the Government of Bangladesh, in collaboration with local, national and international non-governmental organizations (NGOs), has sought to provide contraceptive services, especially in rural areas. Reversible contraceptive methods, including the IUD, hormonal methods (pills and injectables), condoms and foam, as well as male and female sterilization, are offered through NGO and government clinics and field programs. In addition, a large social marketing program sells condoms, foam and pills at subsidized prices through a nationwide network of small shops.

Little care is available for most pregnant women, although government and non-government programs do attempt to provide tetanus vaccinations, nutrition information and health education. The majority of women give birth at home, attended only by relatives or an untrained midwife. Approximately 24,000 women die in childbirth every year and, within one year, 95 percent of the children born to them are also dead.

Every year, an estimated 750,000 Bangladeshi women may resort to abortion, mostly in dangerous, clandestine circumstances. At least 7,500 of them (one in a hundred) die and several thousand others are left sterile or seriously ill. (Induced abortion is legally restricted in Bangladesh, and only the major teaching hospitals are equipped to provide abortions after ten weeks' gestation.) The Government of Bangladesh also provides menstrual regulation (MR) 
services for women who fear they may have an unwanted pregnancy. In all, the practice of MR (both reported and unreported) saves at least 100,000 to 160,000 women in Bangladesh from the dangers of unsafe abortion every year.

While accomplishments in the area of reproductive health have been substantialapproximately one third of reproductive age couples say they use some form of modern contraception-much remains to be done to reach the remaining two thirds. Women who know about and want contraception or MR often have to travel long distances to clinics and wait hours for services. Sometimes, no staff or supplies are available when they arrive and the trip has to be repeated. Women who want to use contraceptives or MR often face strong opposition from their husbands, in-laws or community leaders. As a result, millions of women do not yet have access to family planning and health services, and those who do need to be better served.

\section{The Bangladesh Women's Health Coalition}

The Bangladesh Women's Health Coalition (BWHC), which offers a high standard of reproductive health care at reasonable cost, is an example of what can be done. BWHC was founded in 1980 by Sandra Kabir, with encouragement from the International Women's Health Coalition (IWHC). At the time, Ms. Kabir was working as a program officer in the Southwest Asia regional office of Family Planning International Assistance (FPIA), an agency disbursing U.S. Agency for International Development (USAID) funds to NGOs providing family planning services. One group supported by FPIA was Concerned Women for Family Planning (CWFP), an NGO delivering birth control information and services to women in the slum areas of Dhaka, the capital of Bangladesh. When USAID placed increasingly stringent requirements on CWFP to segregate menstrual regulation from its other services, the agency's director, Mrs. Mufaweza Khan, and Ms. Kabir agreed that Ms. Kabir should establish a separate clinic for women who needed MR.

From one urban clinic focusing on MR, BWHC has grown to include seven multiservice clinics in urban and rural areas. In FY 1989-90, BWHC clinics served approximately 97,000 women and children and provided over 145,000 reproductive health services including counseling, contraception, menstrual regulation, basic children's and women's health care, prenatal care, immunization and referral to hospitals and clinics for other gynecological and obstetric care and for sterilization.

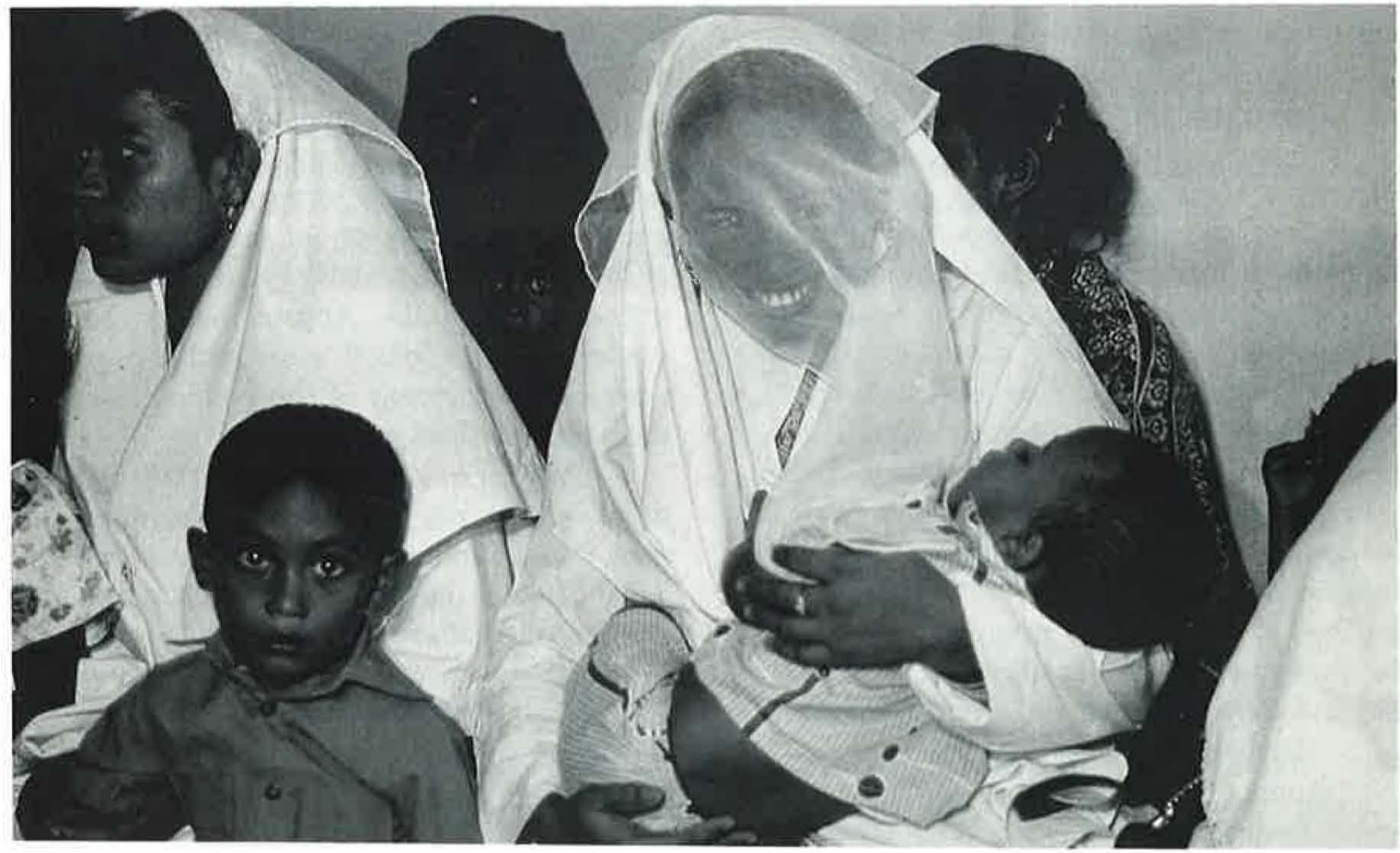


Table 1

\section{Service Mix for All Coalition Clinics and for an Urban and a Rural Clinic}

July 1989 to June 1990

\begin{tabular}{lccr}
\hline Service & All 7 clinics & $\begin{array}{c}\text { Urban } \\
\text { (Mirpur) }\end{array}$ & $\begin{array}{c}\text { Rural } \\
\text { (Bolora) }\end{array}$ \\
\hline Contraception & & (Percent distribution of services) & \\
Menstrual Regulation* & 17.3 & 25.9 & 12.9 \\
Gynecology \& Obstetrics & 8.1 & 15.7 & 3.6 \\
General adult & 9.7 & 8.9 & 5.0 \\
General child & 27.8 & 22.0 & 28.7 \\
Child immunization & 20.9 & 23.8 & 35.5 \\
Total & 16.2 & 3.7 & 14.3 \\
Number of services & $100.0 \%$ & $100.0 \%$ & $100.0 \%$ \\
\hline
\end{tabular}

${ }^{k}$ Including follow-up, deferrals and rejections

From its beginning, BWHC has been managed and staffed primarily by women committed to providing other women with effective and caring contraceptive, health and pregnancy termination services. BWHC's guiding premise is that informed choice is as essential to a reproductive health program as are medical safety and access to contraceptives. Therefore, from the outset, BWHC established the following basic principles for quality care:

- Each woman should be treated with respect;

- Each woman's particular needs should be carefully discussed with her; and

- Each woman should be provided with sufficient information and counseling to make her own choices about her reproductive health.

Designing services to meet these basic principles has required an openness to clients' needs, much experimentation with the means of delivering services and the mix of services offered, and cooperation with government and other NGO programs.

While BWHC was originally founded to provide MR, its openness to the needs of its clientele quickly led to the delivery of more comprehensive services for women and their children. For instance, women coming for MR services told BWHC staff that they also wanted contraceptives and were concerned about the well-being of their children. Mothers often give priority to their children's health over their own, and in Bangladesh, children's health is generally inseparable from that of their mothers. In 1989-90, for example, 25 percent of BWHC's services were for family planning, including MR; 38 percent were for women's gynecological, obstetrical and health problems; and 37 percent were for children's health and immunization.

On average, 1,700 services per month are provided at each of BWHC's clinics, although the number varies according to the clinic and the time of year. For example, women are less likely to visit rural clinics at harvest time or during religious holidays. At one suburban clinic (Narayanganj, southeast of Dhaka), as many as 3,000 clients have received services in one month. The mix of services also varies: MR procedures are in greater demand at urban and suburban facilities than in Bolora, a rural clinic, where the largest share of services provided is for general health and immunization (see Table 1).

No matter what the reason for the initial visit, once at the clinic, all clients learn about and have access to all other services. For example, a nurse's aide, giving an injection to a boy, 


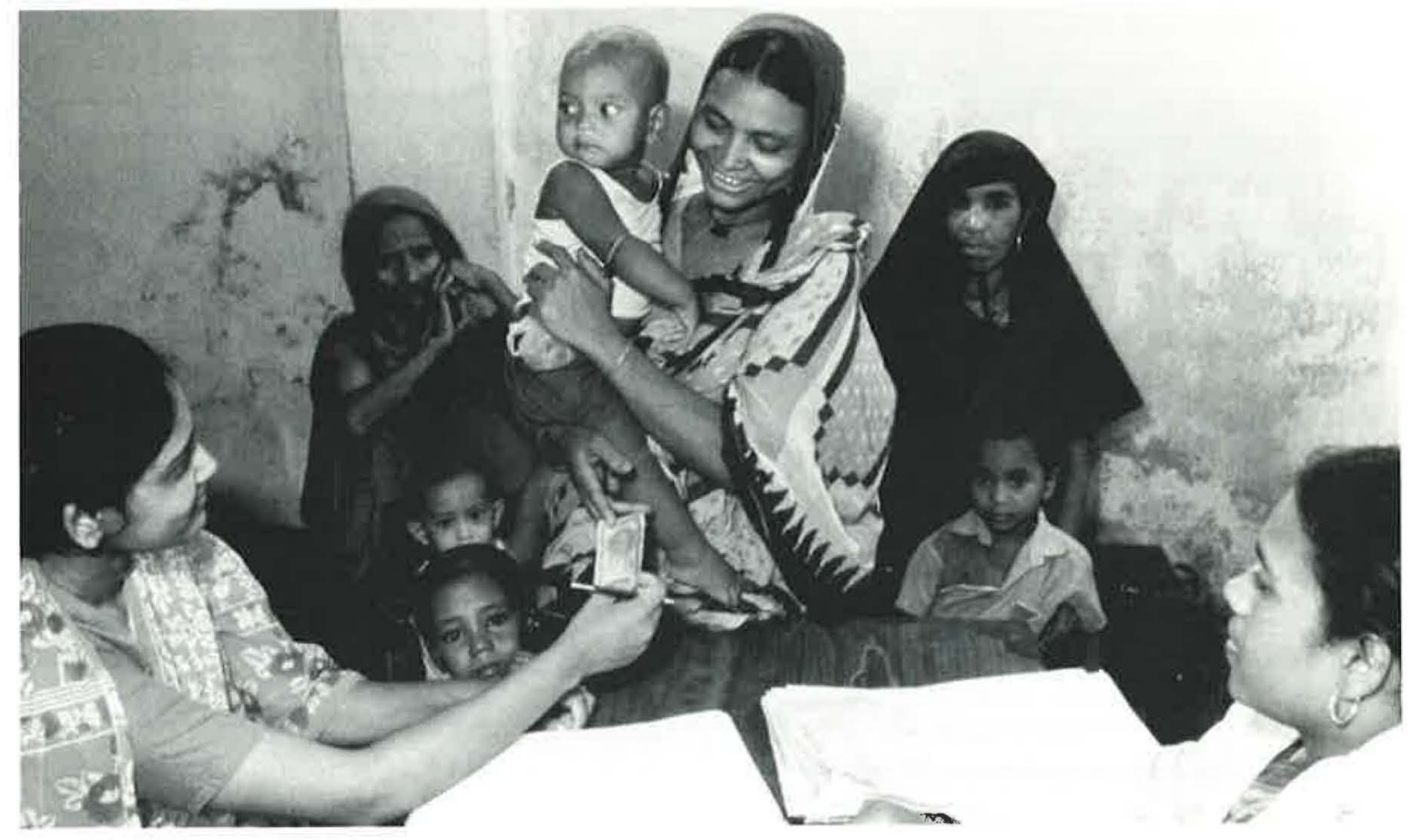

notices his skin is scaly and advises his mother what vegetables to feed him; a client seeing a doctor about her daughter's cough is reminded that she also needs a tetanus shot and they are sent to the paramedic; another client, whose gynecological problem has been successfully treated, requests contraceptive services; and a woman who comes for a contraceptive injection is reminded to bring her children for immunization. Return visits are very high. As one young woman put it, "Everyone knows they give good medicine. It works."

\section{The Service Setting}

All BWHC clinics are open five days a week from 8:00 a.m. until 3:30 p.m. Clients do not make appointments because telephone communication is limited and making an appointment would require an additional clinic visit. On a busy day, a woman could be at the clinic for several hours, but a visit of an hour and a half is more typical. Minimal registration fees are charged at all clinics. The two oldest clinics, both in urban areas, charge fees for services on a sliding scale basis. Since February 1990, nominal service fees also have been charged in the other clinics because paying for services increases clients' self-respect, and because BWHC wants to demonstrate it can be partially self-supporting. A woman's ability to pay is determined by the receptionist or counselor, primarily on the basis of what the woman says and how she appears. However, no one is ever turned away because she cannot pay.

Clinic services are provided in modest buildings in low-income neighborhoods of Dhaka, and in semi-urban or rural areas. Furnishings and equipment are simple, inexpensive and usually locally made. While physical facilities vary, all of the clinics are spotlessly clean and airy, their walls decorated with posters and their windows hung with freshly laundered curtains. Chairs or benches are always provided, as are toilet facilities for clients and their children.

BWHC offers a choice of family planning methods including the pill, injectable, IUD and barrier methods. Counselors discuss all these methods, plus sterilization, with clients. As BWHC does not perform sterilization procedures, a woman choosing this option is referred to the nearest medical facility offering this service. 


\section{Staffing and Supervision}

Family planning services are provided by women paramedics because in Bangladesh women prefer to be treated by women. Whenever possible, paramedics are recruited from the community and are chosen for their interest in serving other women as well as for their professional skills. They must have a minimum of ten years of formal education, and 18 months of government training as Family Welfare Visitors (FWVs). Most of them have also had at least seven to eight years of professional experience. All paramedics are specially trained by BWHC in counseling and medical techniques, and then attend periodic two-week refresher training sessions.

Each BWHC clinic is staffed by two or three paramedics (FWVs), a project coordinator or administrator (who usually has a master's degree), a counselor (who is a university graduate), a nurse's aide who dispenses medicine, two attendants (ayahs) and two guards. All staff, except the guards, are trained to provide health and family planning information to clients. Medical staff are supervised by full-time physicians who also provide all maternal and child health services except immunizations. Two clinics have full-time counselors while the project coordinators serve as the counselors at the other five clinics. In the near future, it is anticipated that all clinics will have full-time counselors so that project coordinators will have more time for community development work.

BWHC's policy is that all staff should not only master the technical aspects of their jobs, but should also demonstrate interpersonal skills. Salary increases and promotion depend on providing not only quantity but quality care. Staff at the newer clinics, who are less experienced, generally receive lower salaries than their counterparts at more established clinics. Performance, however, is always the criterion: One administrator at a newer clinic, who was particularly sensitive to clients and worked long hours, received the highest salary increase ever given to an administrator at the end of her first year.

Following initial screening by a receptionist, clients are directed to the appropriate staff. In the three clinics where there are resident female doctors (Dhaka, Narayanganj, and Mirpur), women with gynecological problems are treated by physicians. At the other four clinics (Palash, Bolora, Tangail, and Lohagara), women are examined by paramedics who work under the supervision of a male doctor.

The basic health care services for women and children offered at all BWHC clinics

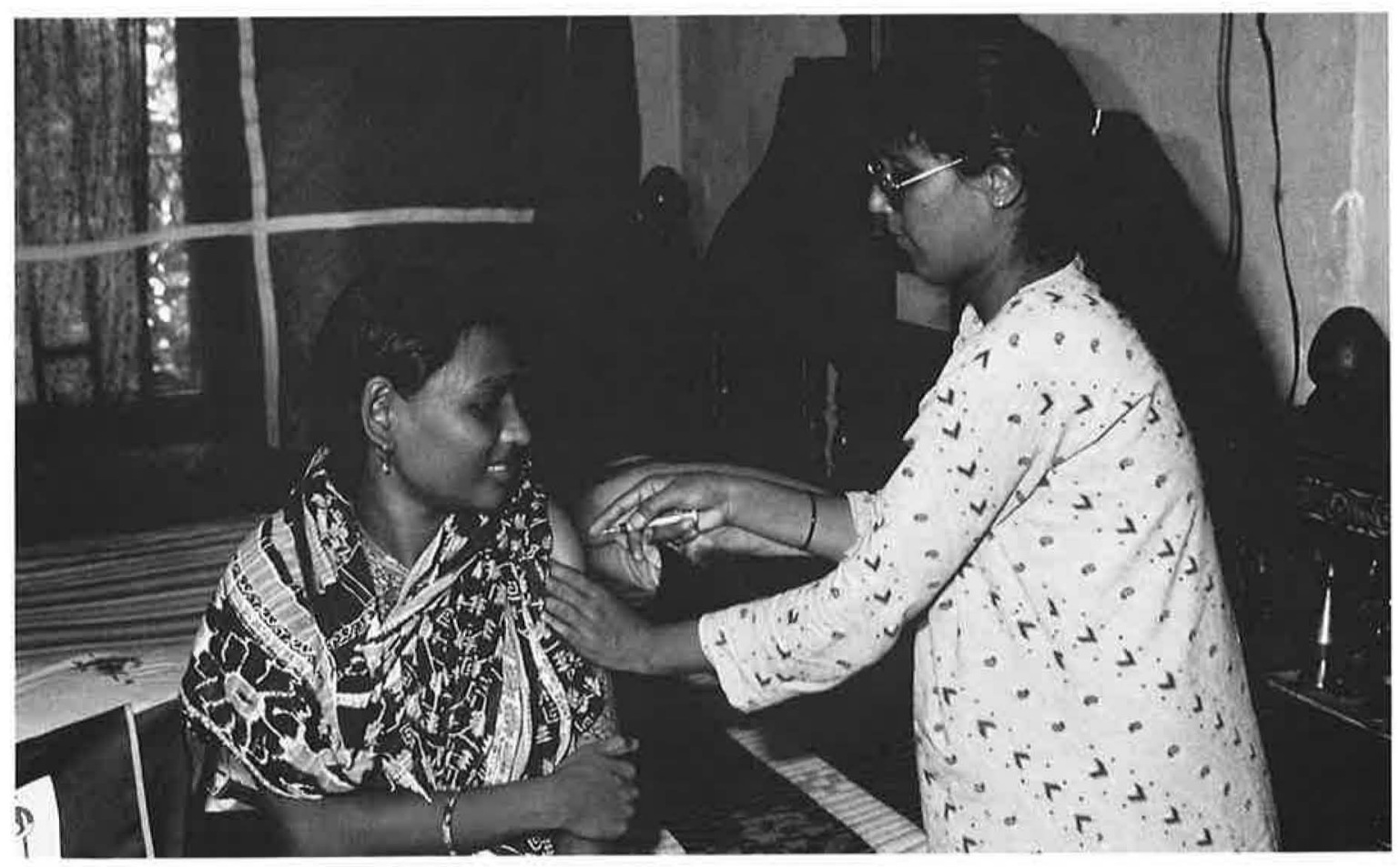


include treatment for primary illnesses such as dysentery, scabies, upper respiratory tract diseases, eye infections and anemia. If diagnosis or treatment of a health problem is beyond the resources of the clinic, clients are referred to other medical facilities. BWHC has established working relationships with a variety of health providers, including government hospitals and private physicians, and a BWHC registration card, with a doctor's comments, is honored by these providers.

\section{The Importance of Counseling}

At BWHC, counseling is an important component in the delivery of all services. The aim is to put the client at ease and encourage her to ask questions as well as to share information with her. Counseling is an aspect of service delivery not widely practiced or understood in Bangladesh. BWHC clinics are unique because not only is there a staff person specifically trained in and responsible for counseling, but most of the clinical staff, including the doctor, the nurse's aide and attendants, are also involved in counseling to some degree. A conscious effort is made to overcome the class barrier that exists between the counselors and most of their clients and to avoid patronizing or condescending attitudes toward clients. This means both the service provider and the client must learn new behaviors in order to participate equally. While an initial counseling session lasts only about 15 minutes, it represents an opportunity offered almost nowhere else in the country.

Although the clinic is usually crowded with clients, their friends and children, women are counseled in as much privacy as possibleeither in a separate room or a curtained alcove. As a family planning client responds to questions about her reproductive history, the counselor seeks to establish rapport and to alleviate any nervousness the client may feel. When all the particulars have been noted, the counselor and client then discuss the woman's knowledge of family planning, her thoughts about what she wants, and the appropriateness of that method for her particular situation. For instance, will her husband use a condom regularly? Can she keep track of taking a pill every day? Does she need to build up her hemoglobin level before having a tubal ligation? Can she travel every two or three months to the clinic for an injection? Does she have health problems that contraindicate the injectable contraceptive or the pill?

This process generally brings to light a great deal of misinformation. For example: "We

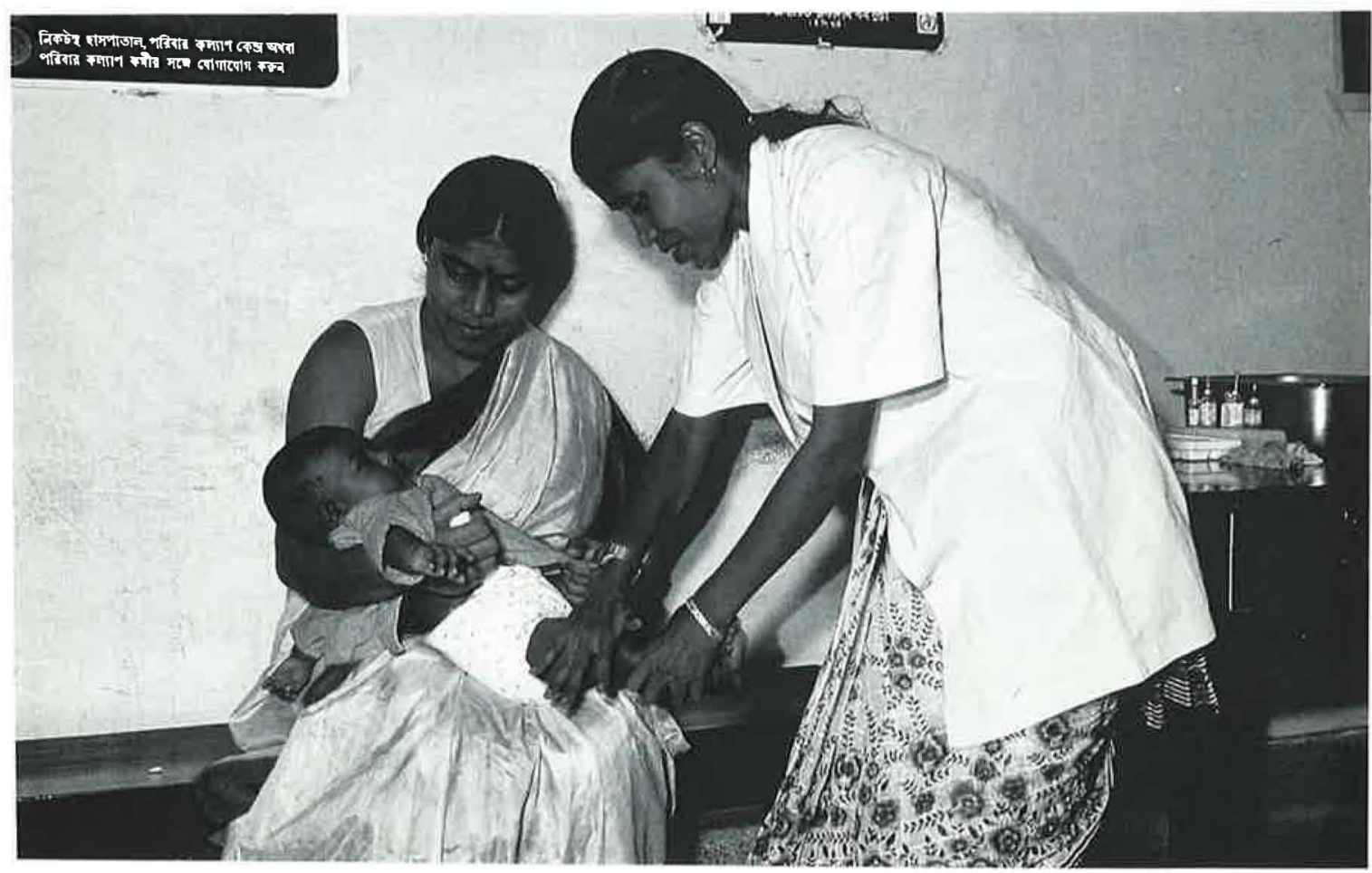




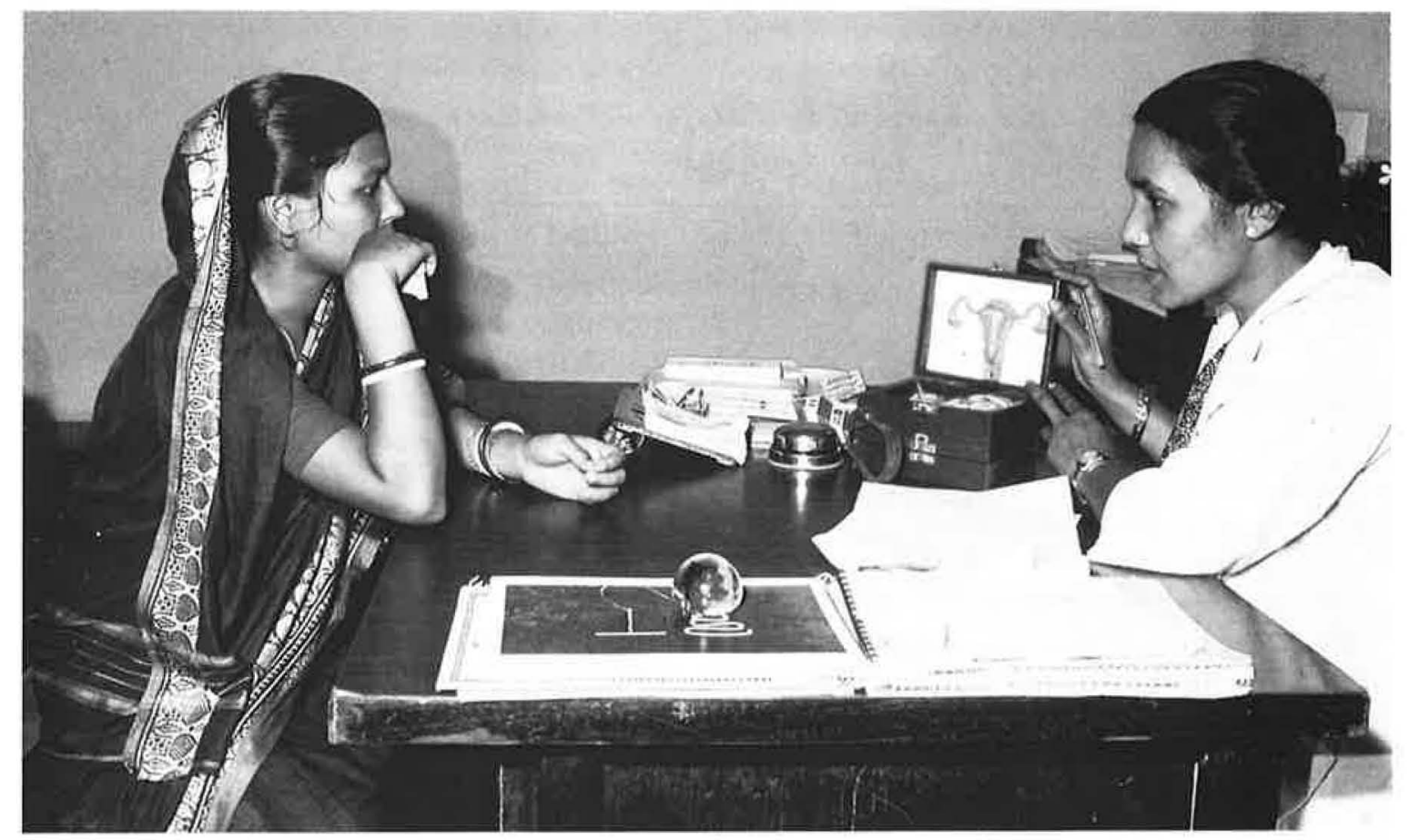

use the condom as much as possible," or "I took the pill on the day I had intercourse," or "I heard that if you had the injection two or three times, you would never get pregnant." The counselor corrects wrong information and, if the client is dissatisfied with her current method of contraception, she helps her consider alternatives. In one case, an MR client who had six children said that the pill made her sick and she did not want to use another contraceptive method after the MR procedure. Discussion revealed that she thought the only other method available to her was sterilization. She was very pleased to learn about the IUD and decided to have one inserted.

Once a decision has been reached, the counselor explains the procedure in detail to the client so she will know exactly what to expect. When appropriate, the counselor will also suggest other services available at the clinic, such as immunization and nutrition education. If husbands accompany their wives, they are encouraged to participate in counseling sessions. The counselor tries to help the client and her husband understand that although no contraceptive method is perfect, a reasonable option can probably be found to meet their needs. For example:

- A woman who experiences nausea and dizziness from the pill, but whose hus- band does not want her to use the IUD, may be advised to try the condom or the injectable.

- A woman who has had eight pregnancies and six children, who is anemic and afraid of sterilization and whose husband refuses even to think of a vasectomy, will be helped to weigh the risks of injectable contraceptives against those of an IUD.

- A woman who cannot use the IUD because her cervix is eroded, whose husband does not want her to have a tubal ligation and who has to walk eight or nine miles to reach the clinic, may be advised to try the pill rather than the injectable. This is because pills can be procured locally whereas the injectable involves a clinic visit every two or three months.

- A woman who does not want another child, and has had an IUD removed because it gave her severe cramps, may be advised to consider sterilization.

A woman's decision about which contraceptive method to use is influenced not only by health considerations but by her partner's preference. The learning process a client goes through with the counselor often brings to light not only intimate human relations, but the power relations that affect a woman's contra- 
Table 2

\section{Contraceptive Method Mix for all Coalition Clinics July 1989 to June 1990}

\begin{tabular}{lccccccr}
\hline Method* & Dhaka & Narayanganj & Tangail & Mirpur & Palash & Bolora & Lohagora \\
\hline \multicolumn{7}{c}{} & \multicolumn{7}{c}{ Percent distribution of methods) } \\
Pill & 44.0 & 49.5 & 38.8 & 46.0 & 57.8 & 36.0 & 49.2 \\
IUD & 5.6 & 6.8 & 16.3 & 9.9 & 14.7 & 21.0 & 5.7 \\
Injectable & 38.7 & 33.7 & 37.5 & 36.2 & 24.5 & 39.4 & 25.9 \\
Condom & 11.7 & 10.0 & 7.4 & 7.9 & 3.0 & 3.6 & 19.2 \\
\hline Total & $100.0 \%$ & $100.0 \%$ & $100.0 \%$ & $100.0 \%$ & $100.0 \%$ & $100.0 \%$ & $100.0 \%$ \\
Number of & & & & & & \\
Services & 4,067 & 5,665 & 3,134 & 3,719 & 1,760 & 1,222 & 652 \\
\hline
\end{tabular}

*Excluding method switches, and referrals for tubal ligation. Percentages refer to services provided, e.g., three-month pill supplies, two or three-month injections, IUD insertion, one-month condom supply.

ceptive choices: Husbands often object to specific methods because of inconvenience to them rather than out of consideration for their wives' health. At BWHC, no particular contraceptive method is promoted; rather each client is urged to make her own choice once she understands the benefits and possible disadvantages of each method. It is made clear to the client that she may return and make a new choice if problems develop or if she changes her mind about the method she has chosen. (See Table 2)

\section{Menstrual Regulation Services}

Menstrual regulation (MR) is vacuum aspiration of the uterus by means of a hand held suction syringe, or an electric pump, connected to a flexible plastic tube called a cannula. MR can be used for diagnostic purposes or to eliminate the possibility of an unwanted pregnancy. No pregnancy test is required, but a careful, bimanual pelvic examination is a prerequisite to determine the exact position and size of the uterus. MR is a simple, low-cost, safe procedure that can be done by a trained paramedic as well as a doctor. It usually takes from three to five minutes, depending on the condition of the uterus and the skill and experience of the provider. In Bangladesh, MR is performed primarily by trained paramedical workers (FWVs).
Approximately 95,000 MR procedures a year are reported in Bangladesh, with most performed in government hospitals and health and family planning clinics. Many more, however, are performed by trained personnel but go unreported. Many NGOs used to provide MR as a basic component of family planning services but discontinued the service in the early 1980s due to USAID restrictions. Today, BWHC is one of two NGOs in Bangladesh providing MR. In 1989-90, 6,523 MR procedures were performed in BWHC clinics.

Although MR clients occasionally want the procedure for social reasons, such as sexual relations outside marriage or before a bride has gone to live in her husband's house, most MR clients are married women of various income levels, ages and parity. The reason they are in need of MR varies: They may not have had access to contraceptives; not having had regular periods since their last delivery, they may not have known they were at risk of pregnancy; they may have experienced a contraceptive failure; or they have used a method incorrectly. For example, a new client seeking MR recently came to a BWHC clinic. She had one child, her husband was using a condom "sometimes," and she was taking the pill only on the days she was having sex.

An MR procedure is performed only if no more than ten weeks have passed since a wom- 
an's last menstrual period, no medical contraindications exist, and she gives her full and informed consent. (Her husband's consent is not required.) Women are not eligible for MR if they have a significant gynecological infection or a serious medical complication.

As awareness of the availability of MR services has increased, more women are coming to the clinic within two to four weeks after a missed period, but even so one out of every four women who request MR has to be turned away because more than ten weeks has elapsed since her last menstrual period. Another 14 percent may be deferred until a medical problem can be corrected. BWHC is attempting, through social workers and word-of-mouth, to encourage women with delayed periods to come to the clinic early.

Whether or not she is eligible for MR, each woman has access to all of the clinic's counseling, medical and family planning services. If she is too late for MR, she will be given counseling and prenatal care and urged not to resort to dangerous, clandestine abortion procedures. If she is eligible for $\mathrm{MR}$, she will be encouraged to use effective contraception after the procedure. While BWHC discourages repeated use of MR, a client is never refused the procedure for this reason. Records show that 88 percent of $\mathrm{MR}$ clients in BWHC clinics use a contraceptive method following an MR procedure. A study of contraceptive use after MR, conducted in 1987-88 at the BWHC clinic in Narayanganj, found that 72 percent of postMR clients were still contracepting one year later.

\section{Record Keeping for Service, Quality, and Evaluation}

The maintenance of accurate and accessible records is a vital component in the provision of high quality care. It requires a system that can provide data on each client's medical history, health problems, recent symptoms and use of clinic services. Data collection, however, must be selective in order to avoid needless repetition that only burdens a system and reduces its effectiveness.

Prior to September 1986, the record system in use at BWHC was extremely complicated, with over 25 different registration books used to record information on each type of service provided. Even with all this data, it was still impossible to know, for example, whether a client who brought her child for immunization had also received family planning services. Therefore, BWHC decided to streamline its

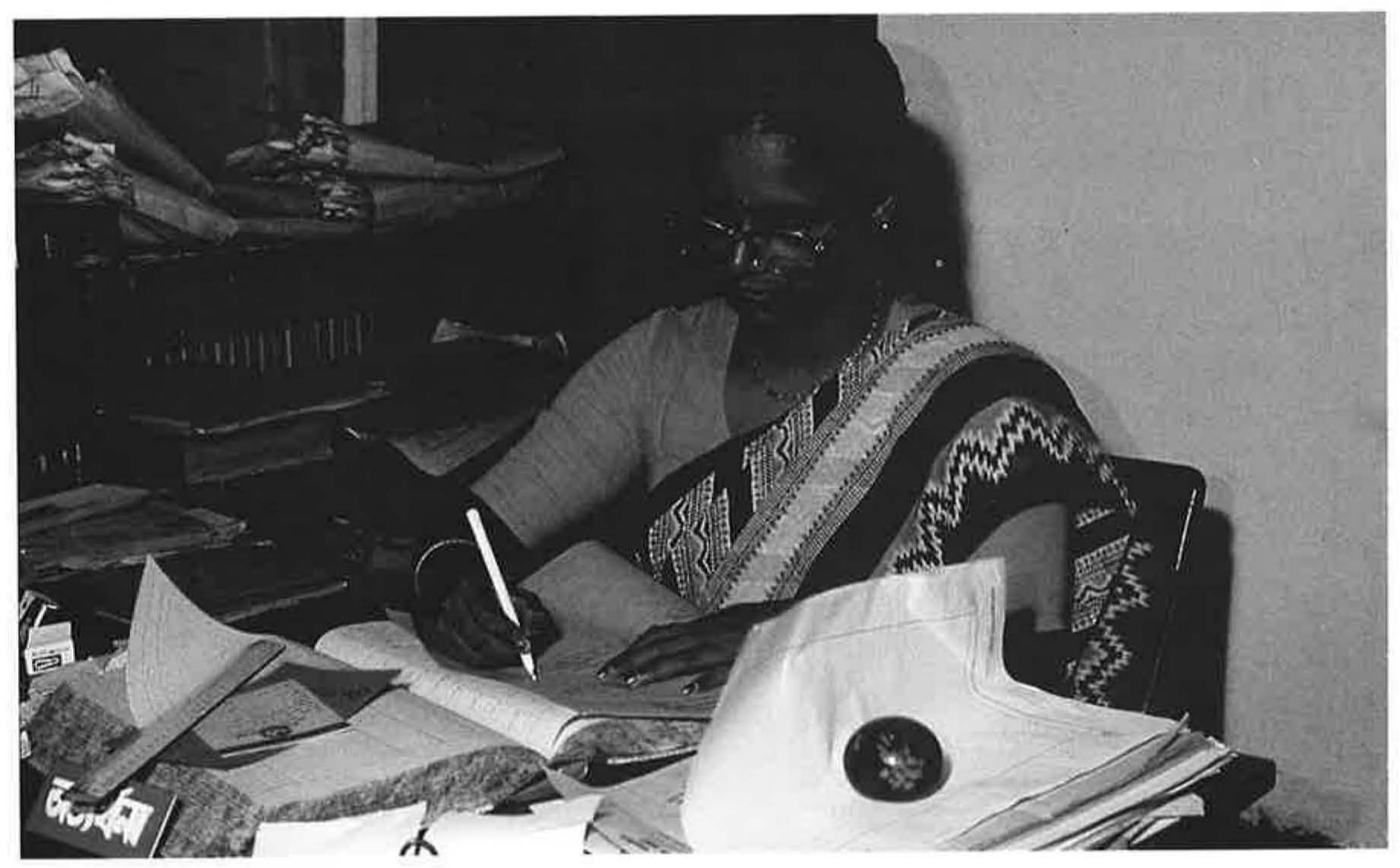


record keeping and design a system that could track a client and not just record services provided. The new system was also designed to help staff better serve the needs of a client's family.

One sign-in registration book is now maintained for all clients visiting a clinic so that if a client has lost or forgotten to bring her registration card, the book serves as a backup. Each family (mother and children) is given a numbered registration card to keep. The card records the name and address of the mother and the names of all her children. There is space on the reverse side to note the dates of follow-up visits for individual family members. In this way, continuity of care can be provided and assessed. The core of the new system, however, is the family file. This file contains service summary sheets and health, family planning and prenatal forms. It is opened at the first visit and is kept at the clinic.

The new system, designed with the input of the service-giving staff, was introduced in all BWHC clinics in September 1986. Now, whenever a staff member provides a service to a client during the course of a visit, she makes a notation on the client's family file and checks off the appropriate box on a service summary sheet kept in the file. At the end of every day, the information from each family file is used to update the clinic's weekly summary sheet. In this way it is possible to assess patterns of clinic use from the information provided by the summary sheet as well as to know the total number of services provided by the clinic. Weekly summary sheets from all the clinics are used to prepare a monthly report for the central office.
The new record system provides BWHC staff with such information as the number of women rejected for MR, and for what reasons; how many women who were first introduced to the clinics through concern for their children's health return for reproductive health care; how many women return for repeated MRs, and how many fail to return for post-MR check-ups. These data have implications for counseling and for management of client flow within each clinic. BWHC's Deputy Director for Research, with the help of her assistant director, is responsible for analyzing this data under the guidance of the Executive Director.

The record system also helps reveal complex management problems. At one of the urban clinics, for example, the number of MRs declined more than 50 percent during a twoyear period, despite increases in other services. At first, staff thought this was a result of competition from private practitioners. A review of client records, however, showed that an unusually large number of women were being turned away because too much time had elapsed since their last menstrual period. Two university students were hired by BWHC to follow-up the rejected clients, using a short interview protocol and a questionnaire prepared by BWHC. Their study revealed that the decline in services actually was due to a senior paramedic who was restricting the work of a junior co-worker with the result that many women who were within the ten week cut-off period were not being served. The senior paramedic was docked two weeks salary and soon the number of MR clients was back to its previous level. 


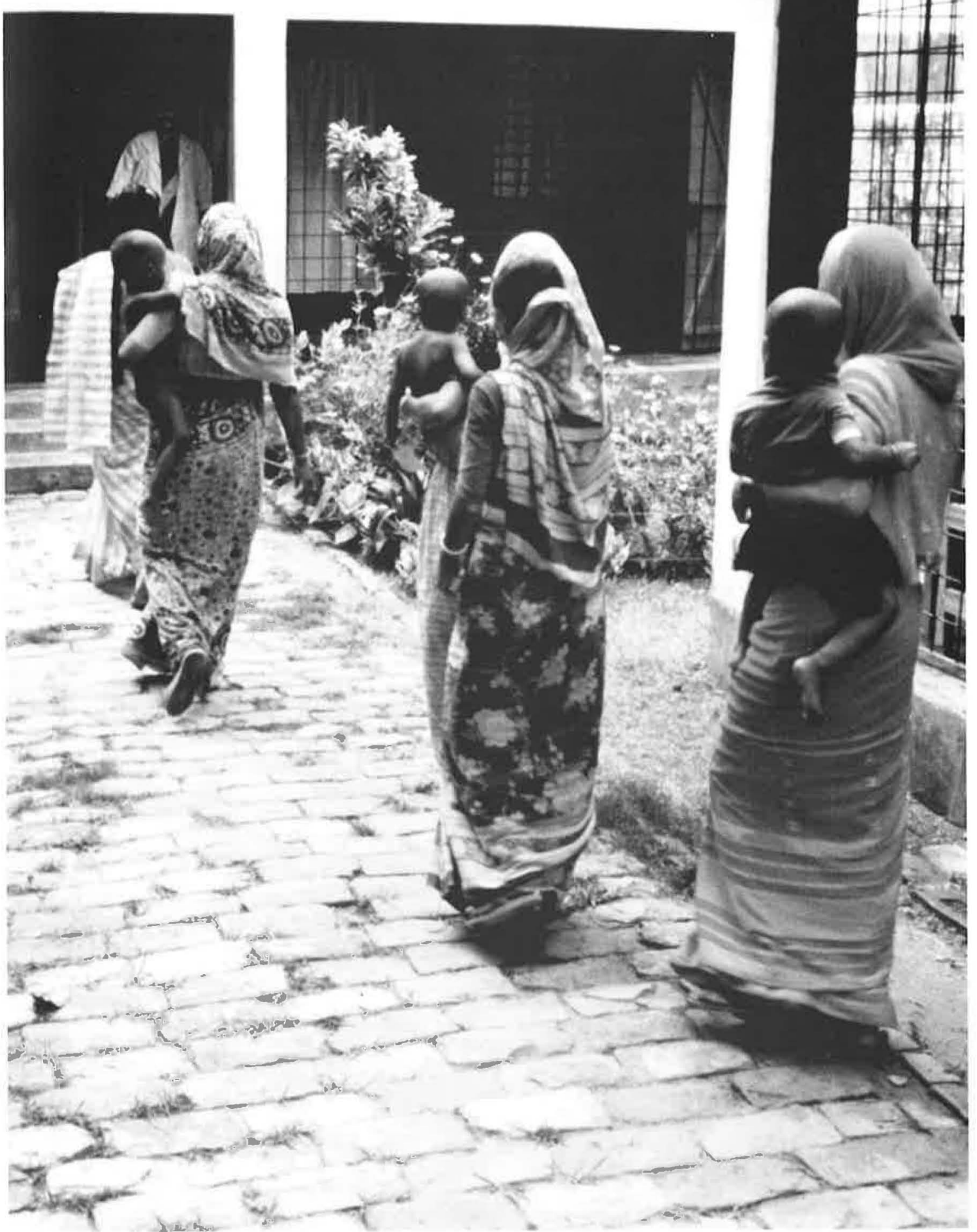




\section{Portrait of a Typical Urban MR Client at the Dhaka Clinic}

Rokeya lives in Dhaka, in a compound with her husband and their two children, her husband's parents, and two brothers and their families. She is 20 years old and has completed primary school. She and her husband want their children to have a good education and the kind of opportunities they themselves have not had. But Rokeya fears she may be pregnant and knows that a third child at this time would jeopardize these dreams. She has heard that there is a $B W H C$ clinic in old Dhaka, about two miles from her home, which provides MR services.

Accompanied by a friend, Rokeya travels to the clinic by rickshaw. Located on the ground floor of an old house, down a narrow road just off a main thoroughfare, the clinic is identified by a prominent BWHC sign board posted on a high wall that screens it from the street. Most of the women who come to the clinic are from neighboring sections of the city. Their education, income and social status vary.

Rokeya walks through a long veranda to the private registration room while her friend waits in a room outside. The registration room has a separate waiting area, with curtains and screens helping to provide privacy. The recep- tionist invites Rokeya to be seated and asks for her name and address. As this is Rokeya's first visit, a registration card is filled out, she is given a registration number and a file is opened for her. The file contains medical and family planning history forms and will become Rokeya's permanent record at the clinic. After about 15 minutes, the project coordinator, who is also the counselor at this clinic, invites Rokeya into her office where they can talk privately.

The counselor describes the MR procedure and explains to Rokeya the various contraceptive methods available for her to choose from after the MR. With the aid of charts, three-dimensional models and a specially designed pamphlet suitable for both non-literate and literate women, she helps Rokeya understand how her body functions and how the various contraceptives work. The session continues until the counselor is certain that Rokeya understands the MR procedure and the contraindications and side effects of the contraceptive methods they have discussed.

From the counseling room, Rokeya is taken by a paramedic to a room where her medical history and vital signs are taken. The paramedic, who will perform the MR, also explains the procedure for Rokeya and answers any additional questions she may have. Next, Rokeya is escorted into the MR procedure room. Screens are used to create a post-procedure rest area and there is a

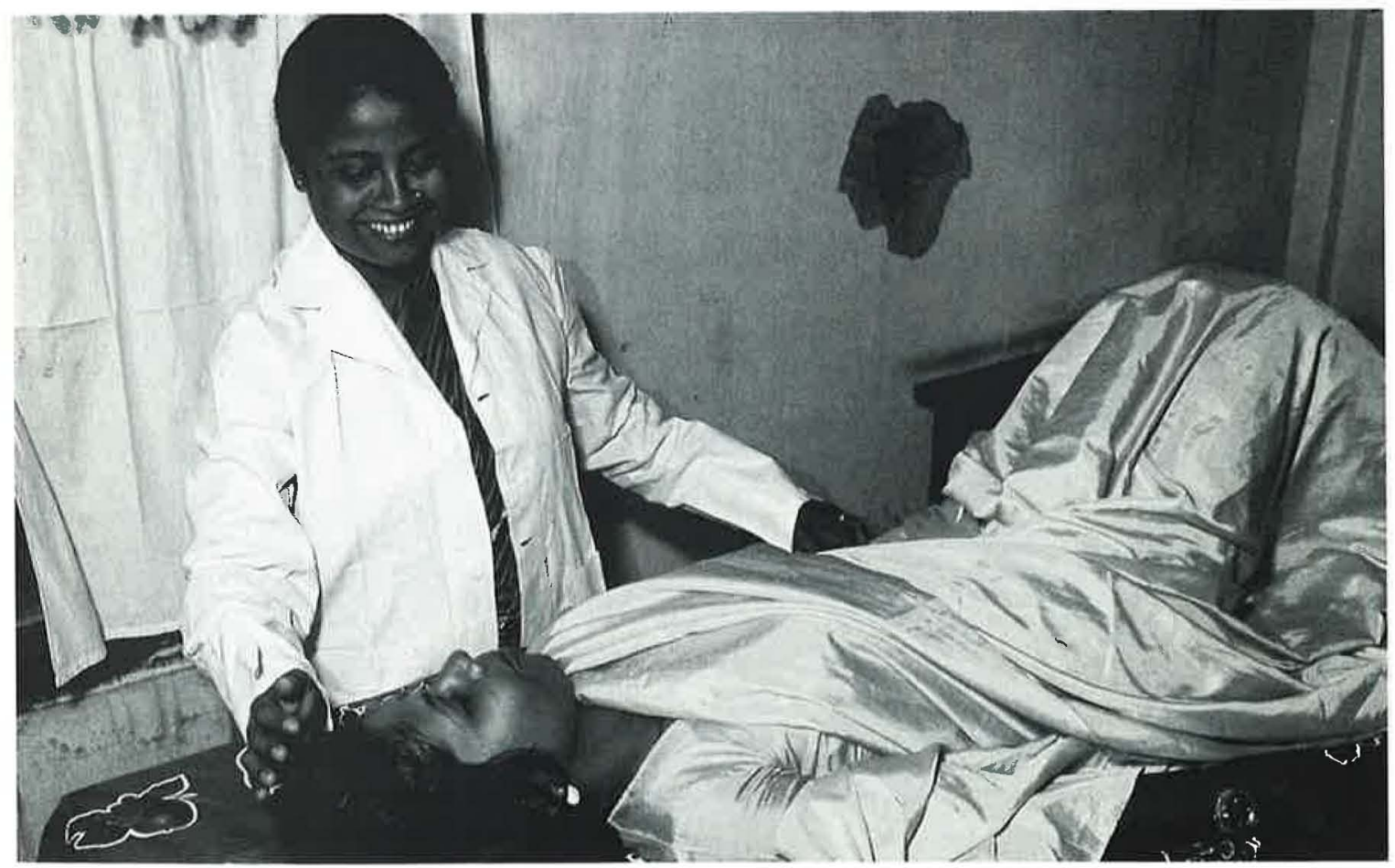


bathroom nearby. The paramedic gives Rokeya a pelvic exam to determine that she has no infection and that gestation is no more than 10 weeks. Rokeya is then made as comfortable as possible on the table and the MR is performed using a hand held plastic syringe and cannula. (No anesthesia is used, but a light sedative or painkiller may be given orally if a client is anxious.) The counselor or another staff member stays with Rokeya during the procedure to comfort and reassure her and to help her relax by talking to her, holding her hand and stroking her forehead.

After resting for about ten minutes, Rokeya is taken to the post-MR rest area where she again lies down. She requests that her friend join her there and she is offered a cup of tea. In the meantime, the paramedic writes the details of the procedure in Rokeya's family file and sends it back to the counselor.

About 30 minutes later, Rokeya again talks to the counselor about the pill, the contraceptive method she has chosen to use. The counselor reminds her how it should be taken and how to manage any side effects she might experience. She gives Rokeya only one cycle of pills so she can have a trial period to determine whether she experiences any side effects. Rokeya is urged to return for a follow-up visit in two weeks, or earlier if she has any concerns. After a visit of about two hours, Rokeya leaves the clinic with her friend, taking with her the cycle of pills and her registration card (which she will bring back with her on every visit).

\section{Profile of Shamima, a Typical Rural Client at the Bolora Clinic}

The Bolora clinic, established in November 1984, is located in the countryside 45 miles due west of Dhaka. To get there from Dhaka, one takes a jeep for one and a half hours, a rickshaw for another half hour and then a country boat for one to two hours, depending on whether or not the boat has a motor. Still ahead is another rickshaw ride over a bumpy road, frequently inaccessible during the rainy season. The road winds through fields, past clusters of mud and tin houses and down lanes lined with palm trees.

The clinic, located at the intersection of two lanes, is one of the few brick buildings in the entire area. White, with blue doors and shutters and a front veranda with a BWHC sign board, the building has been rented to $B W H C$ at very low cost by the chairman of the local village council. It is surrounded by a garden of flowers and vegetables, and enclosed by a split bamboo fence with an archway of flowers growing over it. On busy days when immunizations are given, 200 to 300 women and children sit under nearby trees on rush mats, or in a waiting room erected across from the clinic, providing a brisk business for the fruit and puffed rice vendors.

Shamima is 24 years old and has given birth to six children, two of whom died before their first birthday. Married at 12, Shamima didn't live with her husband and his family until she was 14 years old. She completed only three years of primary school because she was needed at home to help with household chores. Her first child was born when she was 15 and she has borne a child every two years since then. Now her youngest, not quite a year old, is not gaining weight and Shamima is concerned. Accompanied by all of her children, Shamima set out by foot from her village at dawn for the six-mile journey to Bolora.

Shamima enters the clinic and is invited by the receptionist to sit down. The clinic consists of one large room with a smaller room at one side. Hardboard partitions and curtains divide the main room into four sections which are used for registration, medical history, counseling/administration and clinical procedures such as pelvic examinations, IUD insertions and MR. As with all new clients in any BWHC clinic, a registration card is filled out for Shamima, recording her name and address and the names of each of her children. A family file is also opened in her name.

Shamima tells the receptionist she has come to seek help for her youngest son. While she waits with her children for about half an hour (the average wait, which varies depending on how crowded the clinic is that day), Shamima learns that the woman sitting next to her is waiting for something called family planning. The woman tells Shamima that the clinic can give her pills which will prevent her from having more children. Just as she is about to ask the woman more about these pills, Shamima's name is called by the physician.

The room where the physician sees clients is simply furnished and has an examination table and a small kerosene stove for sterilizing instruments. The male doctor asks Shamima about her 


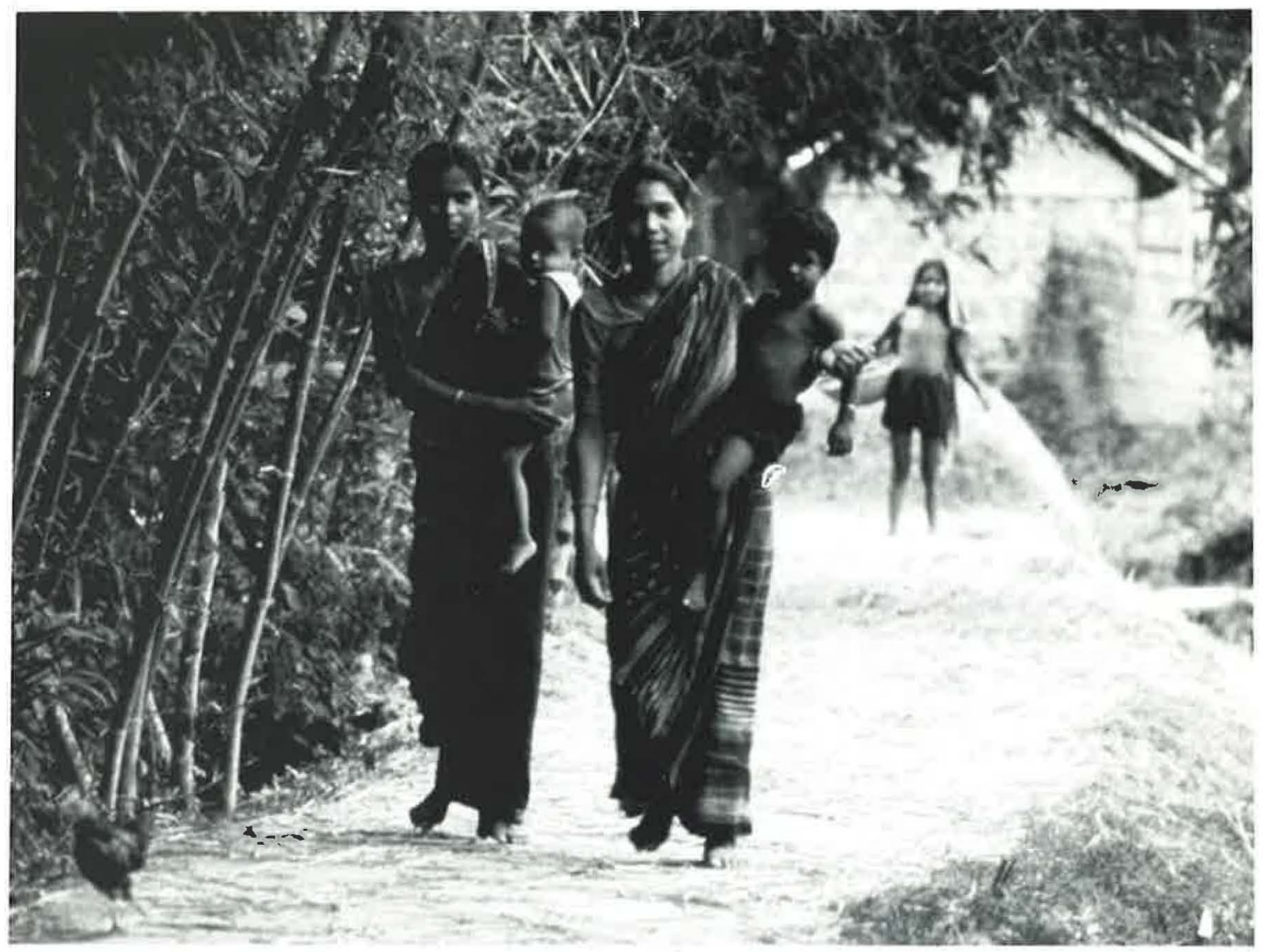

son's medical history and also inquires about her other three children. After examining Shamima's son, and while the nurse's aid dispenses appropriate medication, the doctor tells Shamima how to prepare certain foods her son needs to eat. Shamima leaves the clinic with medicine for her son and the date of her next visit written on the back of her registration card. Next time, she thinks to herself, she will ask someone at the clinic for more information about family planning.

\section{Management Structure}

All seven BWHC clinics are managed by a central office staff consisting of an executive director, a medical director and assistant, and four deputy directors for administration, finance and accounts, research, and community development. Overall policy is the responsibility of an executive council of six prominent Bangladeshi women committed to issues of women's development. They include a social scientist, a professor of gynecology, a lawyer, a researcher and an educator:
The Executive Director is responsible for basic program planning, program monitoring, fund raising, public relations and on-going liaison with the government and other voluntary agencies. She knows each of her 170 staff members by name and her management style is participatory. Management and medical workshops are held periodically with project coordinators and medical staff to discuss progress and resolve problems, and all staff are encouraged to contribute their ideas and suggestions during these meetings. This ensures a sense of team spirit and encourages the kind of smooth working relationships essential to maintaining high standards of morale, commitment and performance. include:

Other members of the management team

- The Medical Director, who is responsible for maintaining medical standards at all BWHC clinics, which she visits regularly. She gives in-service training to the medical staff, arranges for outside training when required and oversees inventories of medical equipment and medicine. She is 


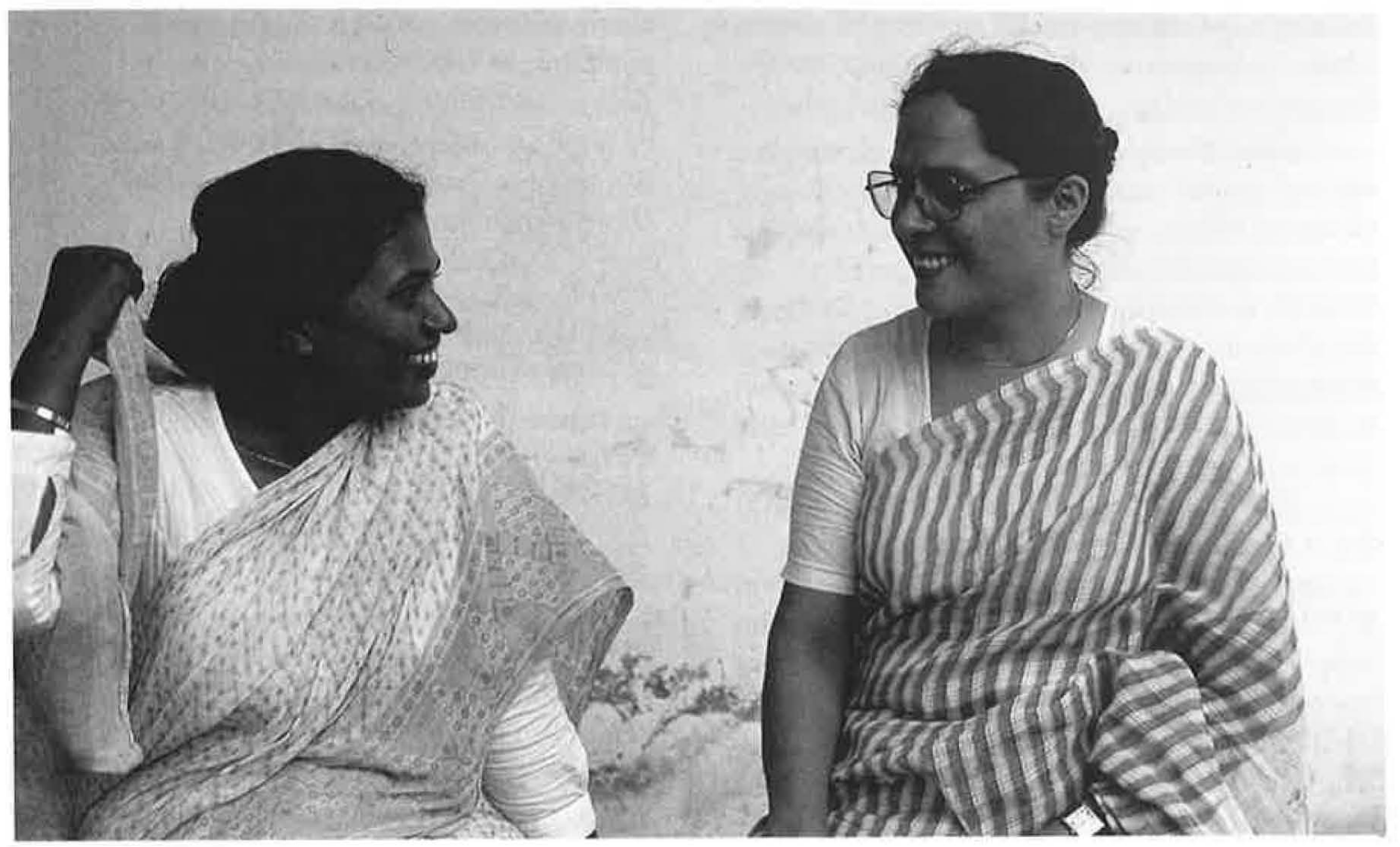

assisted by a senior FWV.

- The Deputy Director for Research, who analyzes clinic data and undertakes special studies on relevant issues such as contraceptive continuation after MR and patterns of clinic use. An assistant director works with her.

- The Deputy Director for Finance and Accounts, who oversees bookkeeping, prepares financial reports, and assists in preparation of budgets for each clinic and for BWHC's central office.

- The Deputy Director for Administration, who runs the central office, makes regular visits to all the clinics, helps staff solve administrative problems, and is responsible for training administrative staff. An important part of her job is to ensure that supplies reach the clinics and that inventories are properly maintained.

- The Deputy Director for Community Development (this is a relatively new post), who supervises and monitors the social workers and their supervisors and oversees the women's literacy program. She is also responsible for BWHC's Cottage Printing Project (see below).

While the central office determines overall policy, the project coordinators in each clinic are encouraged to make suggestions and take initiative on issues specific to their situation. The central office staff, however, try to relieve the project coordinators of much of the management burden by assuming responsibility for raising money, ordering and distributing medical supplies, arranging for acquisition of supplies that may not be available locally and preparing general reports and program assessments.

Keeping seven clinics functioning smoothly in Bangladesh demands excellent management skills plus an extra dose of energy, imagination, creativity and commitment. Three of the clinics have no telephone, and telephones in the other clinics often do not work. Problems must be dealt with on the spot. Information is relayed to the central office by messenger; or saved for discussion with the central office staff during their regular clinic visits.

One important elément in the success of the clinics has been the development of good relationships with community leaders. Local advisory committees have been set up for each clinic to help establish and maintain good rapport with the local community. In Bolora, for example, community support was instrumental in finding a suitable accommodation for the clinic, and in Palash, northeast of Dhaka, community support was essential in gaining accep- 
tance of reproductive health services in an area where conservative religious leaders initially disapproved of both contraception and MR.

Even though the government supplies contraceptives (other than condoms) free of charge to NGOs, maintaining sufficient supplies and equipment is an on-going problem for BWHC, as it is for all family planning NGOs in Bangladesh. BWHC's project coordinators must carefully estimate their needs in advance to ensure that their clients can have an adequate choice of contraceptive methods.

Networking with other health outlets in the community helps to provide sources of referral for supplies on the few occasions when BWHC supplies run out. A case in point is the supply of injectable contraceptives, which are imported by the government for distribution to health organizations. At Narayanganj clinic, which has a large client load and a high demand for injectables, supplies periodically run short due to bureaucratic delays in distribution. This can be extremely problematic for clients who often must travel considerable distances to reach the clinic for their next injection. Since it is very difficult for them to return the next day, or even the next week, they are faced with going without the injection and risking an unwanted pregnancy, finding an alternative source of supply or changing their contraceptive method. To prevent this situation from occurring, the project coordinator tries to anticipate such shortages and locate supplies of injectables at other family planning organizations.

\section{Costs of Services}

BWHC's experience has proved that quality need not be costly. In two urban clinics (the original clinic in Old Dhaka and the clinic in Narayanganj), women who can afford to do so pay for services on a sliding scale according to their means. These clinics are now about 35 percent self-sufficient. The top fees at the Dhaka and Narayanganj clinics are 100 taka (U.S. \$3.13) for MR, 10 taka (U.S. \$.31) for a pelvic examination, 15 taka (U.S. \$.47) for an IUD insertion, and 25 taka (U.S. \$.78) for pathology tests for prenatal clients. (Weekly income for an unskilled worker in Dhaka is about 250 taka; weekly income for an FWV is about 500 taka.) BWHC rates are very low in comparison with the fees charged by private doctors and clinics, which can be as high as 500 taka for an MR procedure. In rural areas, most women are so poor that they pay only a token clinic registration fee of one taka (U.S. \$.03), and a nominal service fee of three taka (U.S. $\$ .10)$ for general health or family planning services; 25 taka (U.S \$.78) is charged for MR, if the client is able to afford it. Mirpur clinic, in a suburban slum area at Dhaka, charges five taka for each health and family planning service, and 100 taka for MR.

Low overhead, high volume and multiple services make BWHC's care affordable by Bangladeshi standards. It costs U.S. $\$ 4.78$ to serve an MR client who adopts contraception following the procedure and then returns for a follow-up visit. If the cost to the client of making the trip to and from the clinic (i.e., income forgone while at the clinic and transportation costs) is included, the cost rises to U.S. $\$ 5.68$.

Initially it was hoped that eventually BWHC would become self-sufficient from fees received for services. However, given the poverty of the majority of its clientele, self-sufficiency is an unrealistic goal. BWHC continues to depend primarily on grant funds (at a level of U.S. \$300-350,000 per year), and on contributions of medical supplies and contraceptives from government and private sources.

BWHC received support from the Population Crisis Committee, the International Women's Health Coalition (IWHC) and the Ford Foundation for its earlier work. Currently, the Coalition receives support from the Ford Foundation, the Swedish International Development Authority (SIDA), the British Overseas Development Agency (ODA) and the Danish International Development Agency (DANIDA). The International Women's Health Coalition (IWHC) provides technical assistance and moral support.

In 1987, BWHC started an income-generating project, with support from CIDA and NORAD, with the intention of reducing BWHC's dependency on outside donors. The Coalition's Cottage Printing Project now employs 25 people who silk screen fabrics for Dhaka businesses and design and produce greeting cards, tie-dye saris, and silk screened or block printed tablecloths, napkins and bed- 
spreads. This project is now operating without outside assistance and should begin to generate profits in the next year.

\section{$B W H C$ as a Training Resource for the Government}

Since BWHC clinics serve only a tiny fraction of Bangladeshi women, the Coalition provides free clinical training in family planning service delivery for paramedics (FWVs) enrolled in government training programs and in-service refresher training programs. This service, which has been in operation since 1982 , not only helps BWHC maintain a cordial relationship with the government but serves to introduce government health workers to high quality, comprehensive care.

Every year initial training for approximately 60 government FWVs, and refresher training for $100 \mathrm{FWVs}$, is provided at the clinic in old Dhaka and at the Narayanganj, Tangail and Mirpur clinics. The training covers MR procedures, IUD insertions, pelvic examinations and associated pathological tests. All trainees are introduced to BWHC's counseling approach and basic principles for high quality care. Teaching is based on the BWHC experience and is provided by the senior paramedic, the project coordinator and the doctor in each clinic. The two to three-week training program includes:

- The importance of counseling in effective family planning-qualities of a good counselor, goals of contraceptive counseling, the most common mistakes made by counselors, how staff can help clients select the best options and "how do I know if I am a good counselor?"

- Methods of family planning-how different methods work; side effects and contraindications of the pill, IUD, injectables, condoms, vaginal spermicides, periodic abstinence, female sterilization and vasectomy, withdrawal and hormonal implants.

- MR-the procedure and possible side effects.

- Female reproduction-what every woman should know about her body including the monthly cycle, conception and the course of pregnancy.

- Referrals, resources and aftercare.

BWHC also works to strengthen the policies and programs of other health and family planning service providers, especially government sponsored programs, since even small changes can greatly improve women's access to services. For example, it is important to let

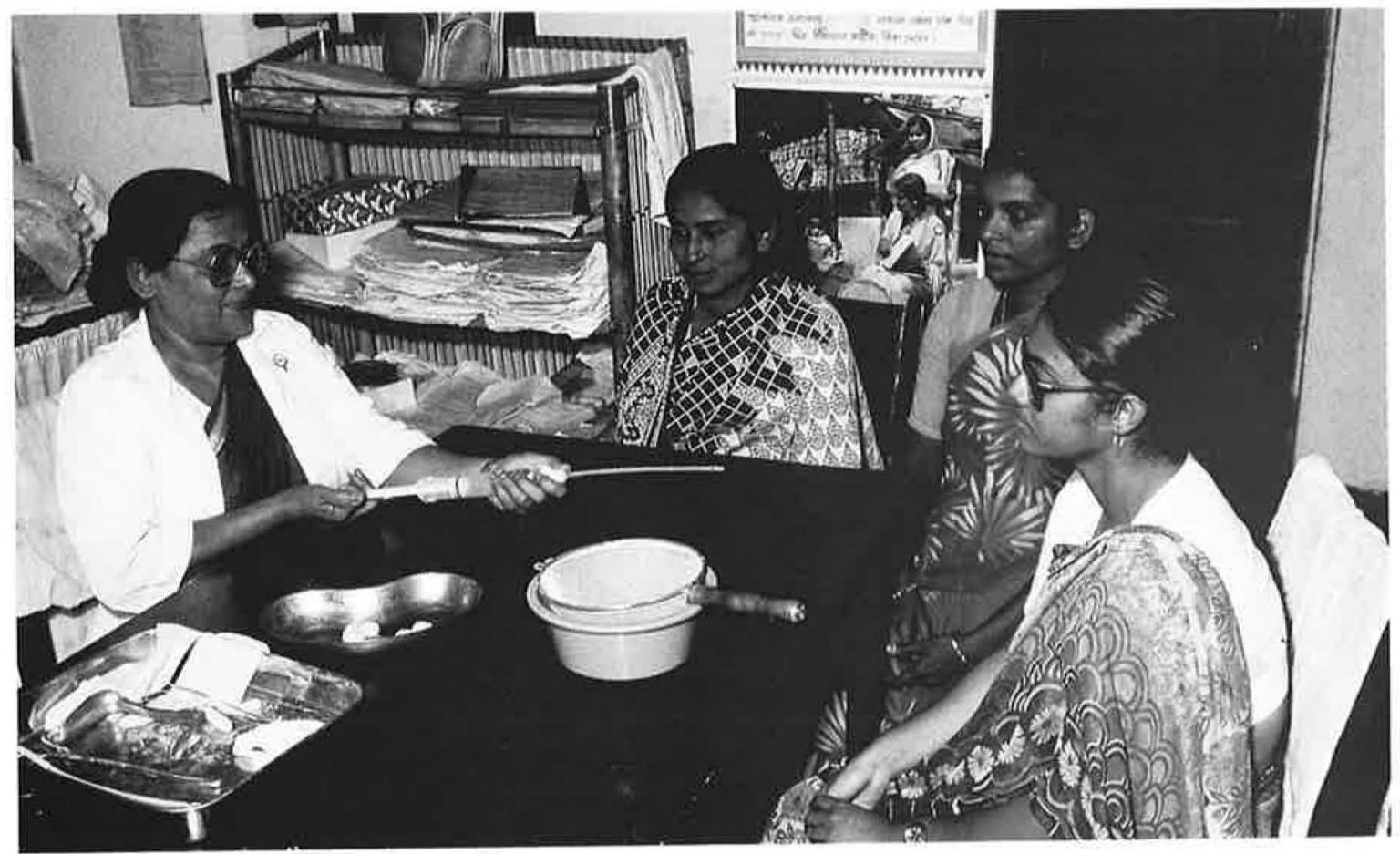


women know not only that MR services are available, but that they must not delay in going to a clinic once they determine that their period is late. There is a substantial network of government FWVs who could provide this important information to village women, but they need to be trained and motivated.

\section{Looking to the Future}

As part of its attempt to better serve women, BWHC continually looks for ways to improve its effectiveness both through expansion of clinical services and experimentation with new activities aimed at improving the quality of women's lives. As Bangladeshi women develop the courage to use health care services, as they come to expect quality care and learn to make choices about their health, they will grow in strength and dignity. They can hope-and work for-better lives for themselves and their children.

Although knowledge of the health services BWHC provides spreads quickly by wordof-mouth (clinics are well-utilized within a few months of opening), BWHC has recently added four social workers and a community supervisor to the staff of each clinic. Their job is to increase community awareness of clinic ser- vices, escort clients to the clinic when necessary, help women understand the importance of timely and regular use of health services and, when possible, visit clients in the immediate area who have missed a scheduled follow-up. Social workers also carry out surveys in the surrounding community to assess health and family planning needs and, when appropriate, refer people to other community resources.

As a result of demand from clients, BWHC also provides adult literacy classes in all seven clinic areas. These classes are held daily for groups of 15 women over a six-month period, and are taught by BWHC community development staff. Other services offered by BWHC include saving schemes and loans for individual income-generation projects, such as opening a food stall or buying a milk goat. Lectures are held once a week in each community where there is a BWHC clinic on topics such as nutrition, family planning and legal rights. Staff members also give periodic lectures in the clinics to waiting clients on health related topics such as infant care, breast feeding or immunizations.

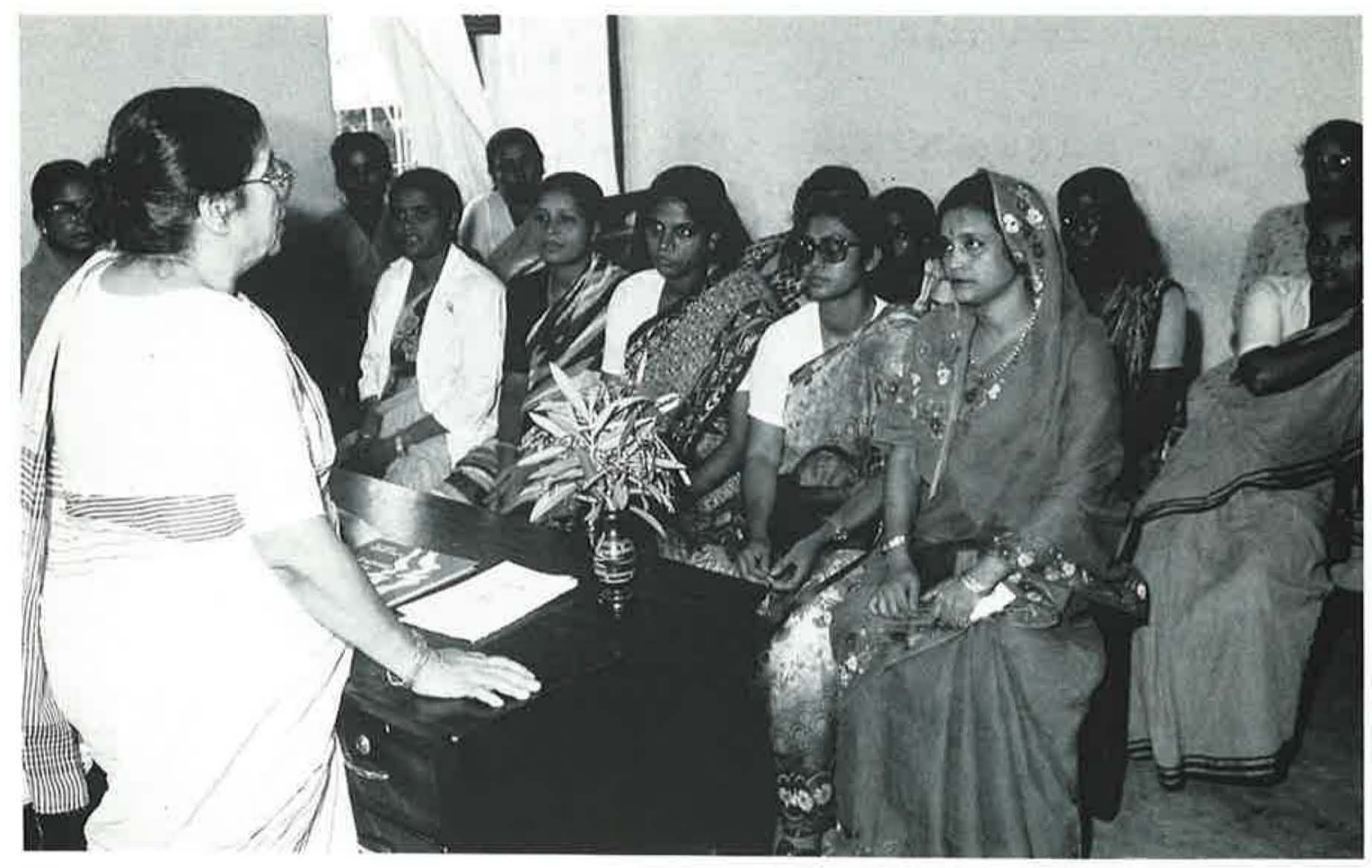




\section{Lessons Learned}

One of the real strengths of BWHC has been its willingness to learn from experience and to continually modify its range of services and mode of service delivery to better address the needs of its clients. BWHC clinics are not intended to be models for replication, but are examples of what can be done to develop high quality services with limited resources.

Some specific lessons that can be drawn from BWHC's experience include the following.

1. High quality services are not a luxury. BWHC has clearly demonstrated that quality care can be attained at per capita costs considerably below those of standard family planning clinics, many of which are under-utilized. Savings accrue in part from: the attractiveness of the services and settings, which keep attendance high and spread fixed costs over larger numbers; from providing a mix of services so that clients can use a visit for more than one purpose, which lowers the cost per service; and from using well trained paramedical personnel instead of physicians for pelvic examinations, IUD insertions and MR. In addition, simple gestures such as treating clients with respect, keeping clinics clean and cheerful and ensuring privacy, cost very little yet are highly valued by clients.

2. The role of counseling goes beyond just giving information. The availability of empathetic counseling creates an environment of choice for all clients. Women are encouraged to care about their own health needs and to understand that their health is also important for their children's well-being.

3. When clients are satisfied with one service, they'll return to try others. BWHC clinics expose many women coming for child health care to family planning information that otherwise might not be available to them. As these women gain confidence in utilizing the child health services, their initial hesitation about reproductive health care is overcome. Similarly, family planning clients are encouraged to seek child health care.

4. The availability of MR, along with contraception, makes family planning and health services accessible to more women. The inclusion of MR means that women who fear they are pregnant can feel welcome at BWHC clinics, and those women who decide to terminate an unwanted or badly timed pregnancy are able to do so safely and in an atmosphere of emotional support. Client records show that most MR clients are first-time visitors to BWHC clinics and have never used contraceptives. If MR was not available, many of these women would resort to dangerous, clandestine abortions. Almost all women receiving MR leave with a contraceptive method and a follow-up appointment, thus facilitating a long-term commitment to family planning.

5. Positive treatment of clients begins with positive treatment of staff. Good management means creating an environment where staff feel they have a voice in making decisions and where they are treated with respect. This, in turn, has a positive effect on the way staff interact with clients. BWHC's participatory management style engenders responsiveness to and communication with clients, both of which are essential to the provision of quality health care services.

6. Client-centered record keeping is essential to quality care. Records, though simple, must be well designed and properly used to facilitate monitoring initial and follow-up care for each client. BWHC's experience demonstrates that records can serve client needs and improve program performance. Service statistics are also a valuable research tool for program planning and evaluation.

\section{References}

For more information about BWHC, write to the Bangladesh Women's Health Coalition, House 46-A, Dhanmondi Rd., Dhaka 1205, Bangladesh. To learn more about the work of the International Women's Health Coalition, write to IWHC, 24 East 21st Street, New York, N.Y. 10010, U.S.A.

For additional information about menstrual regulation, contact IPAS, 301-303 East Main Street, Carrboro, N.C. 27510, U.S.A. 


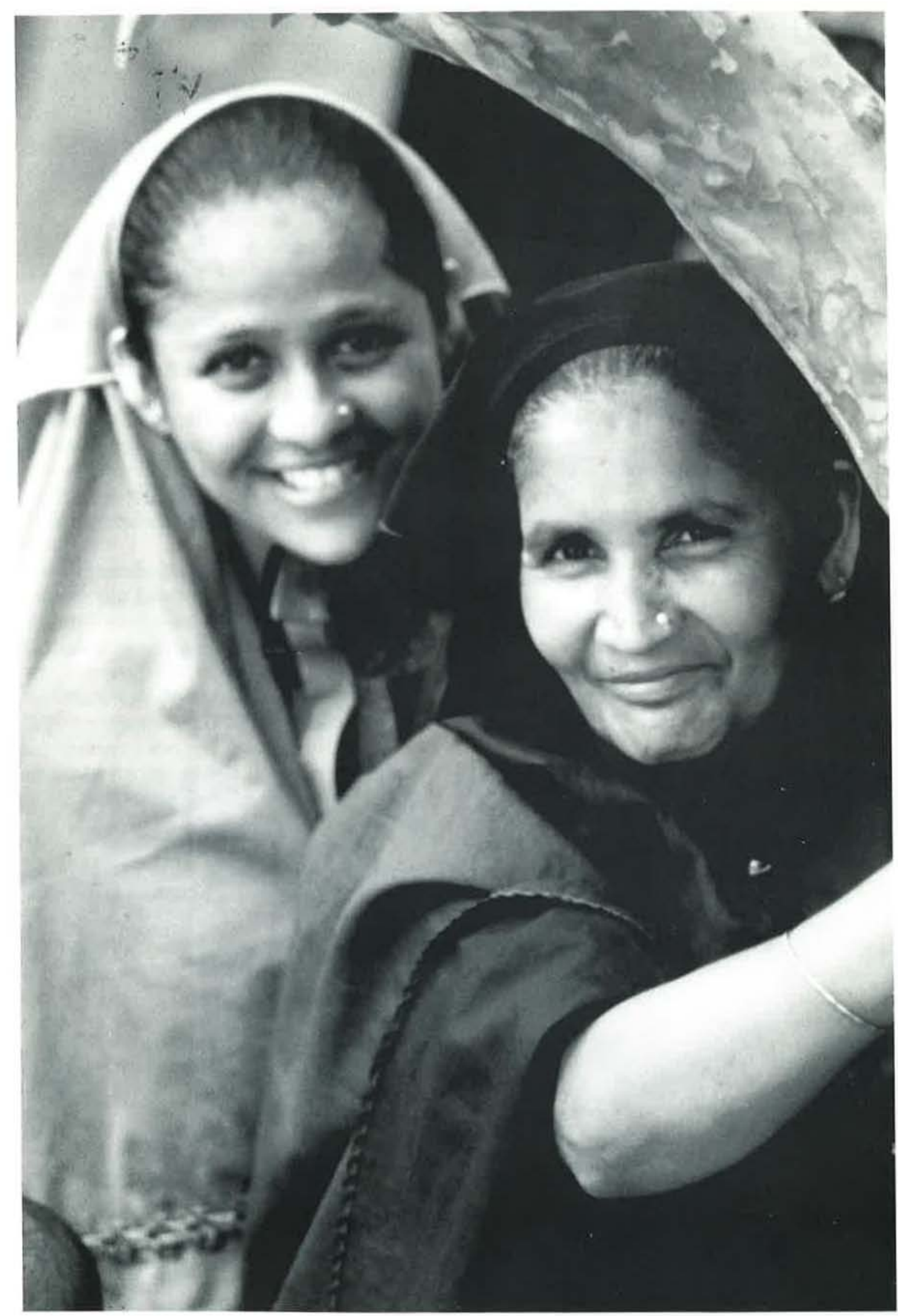




\section{Résumé en Français}

La Coalition pour la Santé des Femmes du Bangladesh (Bangladesh Women's Health Coalition, BWHC) est une initiative importante dans l'évolution vers un mode de distribution des services de planification familiale plus personnalisé. Depuis son ouverture en 1980, comme clinique spécialisée où les femmes en situation de détresse du fait de leur état de grossesse pouvait obtenir une "régulation menstruelle" (c'est-à-dire, l'aspiration par le vide de l'utérus au moyen d'une seringue de succion actionnée soit manuellement, soit par une pompe électrique) la Coalition n'a cessé de croître et comprend à présent sept cliniques, réparties en milieu urbain et rural, offrant une gamme étendue de services.

Bien que sa structure administrative et financière soit similaire à celle de toute autre clinique privée, la BWHC se distingue nettement des autres cliniques par sa philosophie, sa conception, et sa détermination à traiter les femmes avec dignité. Les cliniques de la BWHC sont des endroits accueillants, où les clients sont mis à l'aise, se sentent respectés et compris. Un des objectifs principaux étant de leur donner la possibilité de faire un choix avisé, notamment en mettant à leur disposition un large éventail de méthodes contraceptives, y compris l'interruption volontaire de grossesse à un stade peu avancé. Une autre particularité des cliniques de la BWHC réside dans le fait que la planification familiale n'est pas séparée des autres services de protection de la santé des femmes et des enfants. En effet, des services destinés à traiter d'autres problèmes de santé importants, tels que les problèmes gynécologiques et les maladies infantiles y sont également dispensés.

Dès le départ, le personnel de la BWHC a été composé presque exclusivement par des femmes. Leur principe de base a toujours été que la qualité de la communication entre le conseiller et le client occupe une place tout aussi importante dans un programme en santé reproductive que la prévention médicale et l'accès aux services. En effet, il convient de traiter chaque femme avec respect, de discuter avec elle de ses besoins, et de lui fournir le plus d'informations possible pour lui permettre de faire son propre choix en matière de santé reproductive.

A la Coalition, posséder des connaissances techniques approfondies ne suffit pas; en effet, les membres du personnel doivent également faire preuve d'aptitudes interpersonnelles. Les augmentations de salaires et les promotions ne sont pas uniquement fonction de la quantité de soins prodigués mais dépendent surtout de la qualité. Informer et donner des conseils sont une composante essentielle des services fournis par la BWHC, l'objectif étant de mettre le client à l'aise et de l'encourager à poser des questions et à se confier au conseiller:

Au cours de l'année budgétaire 1989-90, les cliniques de la BWHC ont traité environ 97,000 fermmes et enfants et le nombre total de soins fournis s'est élevé à 145,000 . La BWHC a réussi à démontrer que qualité n'est pas forcément synonyme d'onéreux. Des frais généraux peu élevés, un volume d'activités important, et des services multiples font que les soins offerts par la BWHC sont à la portée des habitants du Bangladesh. Par exemple, le coût total par cliente qui obtient une "régulation menstruelle", adopte une méthode contraceptive, et retoume à la clinique pour une visite de suivi, s'élève à $\$ 4,78$.

A l'heure actuelle, BWHC est l'une des deux seules ONG à pratiquer la "régulation menstruelle" au Bangladesh. La "régulation menstruelle" est une procédé simple, peu coûteux, qui peut être réalisé par un médecin ou par un personnel paramédical ayant, au préalable, suivi un stage de formation. Chaque année, environ 95,000 RM sont réalisées au Bangladesh, la plupart d'entre elles dans des hopitaux publics. Au cours de l'année 89-90, les cliniques de la BWHC en ont effectuées 6525.

En raison de sa capacité d'accueil limitée, la Coalition a, depuis 1982, donné des cours de formation gratuits sur la planification familiale à l'intention du personnel paramédical suivant un stage de recyclage pour le compte du gouvernement. Ce service permet à la BWHC de maintenir des rapports cordiaux avec le gouvernement et d'initier les agents de santé gouvernementaux à la notion de qualité des soins.

Une autre activité de la BWHC consiste à renforcer les politiques et programmes d'autres prestataires de services de planification familiale et de santé, notamment les programmes parrainés par le gouvernement, puisque des changements mêmes minimes peuvent améliorer de façon considérable l'accès aux services et leur qualité.

En réponse à de nombreuses demandes de la part de leurs clients, la BWHC a décidé d'offrir des cours de lecture et d'écriture, ainsi que des programmes d'épargne et de crédit pour venir en aide aux femmes voulant se mettre à leur propre compte. Une fois par semaine, chaque clinique organise une conférence sur des sujets tels que la nutrition ou la planification familiale. De temps à autre, les membres du personnel donnent également des conférences sur le type de soins à prodiguer aux nourissons, l'allaitement au sein ou la vaccination.

Dans une société où le rôle social et la liberté de mouvement de la plupart des femmes et des jeunes filles sont extrêmement restreints, la BWHC s'est fixé comme objectif ambitieux de permettre aux femmes-quel que soit leur niveau d'éducation ou leur revenu-d'apprendre à gérer leur propre santé et celle de leurs enfants de façon à pouvoir pleinement s'assumer et se réaliser en temps qu'individu. 


\section{Resumen en Español}

La Bangladesh Women's Health Coalition (Coalición para la Salud de la Mujer de Bangladesh, o BWHC) representa una iniciativa importante en el movimiento hacia modos de entrega de la planificación familiar que responden a las necesidades de la cliente. Fundada en 1980 con el propósito de proveer regulación menstrual (RM) (que consiste en la aspiración del útero por medio de una jeringa de succión manual o una bomba eléctrica, un procedimiento simple y económico que puede ser ejecutado por un médico o un auxiliar médico entrenado) para mujeres preocupadas por la posibilidad de un embarazo no deseado, la BWHC actualmente cuenta con siete clínicas de servicios múltiples, en sectores urbanos y rurales.

Aunque la BWHC se basa en el modelo convencional de la clínica de salud independiente, se distingue de lo tradicional por su filosofía, espíritu y compromiso con el tratamiento digno de la mujer: Las clínicas de la BWHC son lugares dondes las clientes se sienten bienvenidas, cómodas, respetadas y comprendidas. Se mantiene un énfasis en la elección informada de una amplia variedad de métodos de control de la natalidad, incluyendo la terminación temprana del embarazo no deseado. Las clínicas de la BWHC también son singulares por negarse a separar a la planificación familiar de las otras necesidades de salud de las mujeres y de sus niños. Los servicios para otros importantes problemas de salud, como ser los problemas ginecológicos y las enfermedades infantiles, se proveen en el mismo local.

Desde sus comienzos, la gerencia yzed personal de la BWHC han estado integrados princtipámente por mujeres. La premisa fundamental del personal ha sido que la elección informada es tan esencial a los programas de salud reproductiva como lo son la seguridad médica y el acceso a los servicios. La BWHC ha determinado que cada mujer debe ser tratada con respeto, que sus necesidades particulares deben ser cuidadosamente repasadas con ella, y que debe ser provista de suficiente información y consejería como para que pueda hacer una elección propia sobre su salud reproductiva.

La política de la BWHC requiere que todo miembro del personal no sólo esté completamente capacitado en los aspectos técnicós de sus tareas, sino que también demuestre habilidad para las relaciones interpersonales. Las promociones y los aumentos en los salarios dependen no sólo de la cantidad de atención provista, sino de su calidad. La consejería es el componente esencial de la entrega de todos los servicios en la BWHC, ya que el objeto de los mismos es lograr que la cliente se sienta cómoda y motivarla a que haga preguntas, además de brindarle información.

En el año fiscal de 1989-1990, las clínicas de la BWHC atendieron a aproximadamente 97.000 mujeres y niños, y proveyeron más de 145.000 servicios de salud reproductiva. Las clínicas han demostrado que la calidad no tiene que ser cara. Gastos bajos, alto volúmen, y servicios múltiples hacen que la atención de la BWHC sea económica en términos de la situación de Bangladesh. Por ejemplo, la BWHC requiere de sólo US $\$ 4,78$ para servir a una cliente de RM que adopta anticoncepción después del procedimiento y luego regresa para una visita de seguimiento.

En la actualidad la BWHC es una de las dos organizaciones no-gubernamentales que ofrecen la regulación menstrual (RM) en Bangladesh. Aproximadamente 95.000 procedimientos de RM se reportan anualmente en Bangladesh, y la mayoría se realizan en hospitales del gobierno. En 1989-1990, se realizaron 6.523 procedimientos de RM en Jas clínicas de la BWHC.

Ya que las clínicas de la BWHC sólo pueden servir a una pequeña proporción de las mujeres, desde 1982 la Coalición ha provisto entrenamiento clínico gratuito en la entrega de servicios de planificación familiar a auxiliares médicos inscriptos en programas de entrenamiento del gobierno. Este servicio permite que la BWHC mantenga una relación cordial con el gobierno, y ayuda a introducir el concepto de la atención comprehensiva, de alta calidad, a los trabajadores de salud del gobierno.

La BWHC también busca fortalecer las políticas y los programas de otros proveedores de servicios de salud y planificación familiar, especialmente en los programas patrocinados por el gobierno, ya que un ṕequeño cambio puede mejorar significativamente tanto el acceso de las mujeres a los servicios, como la calidad de los mismos.

Como respuesta al pedido de clientes, la BWHC actualmente provee clases de alfabetización para adultos en cada una de las siete clínicas, además de programas sobre ahorro y préstamos para asistir a las mujeres en la creación de proyectos individuales de generación de ingresos. Una vez por semana, cada clínica patrocina charlas sobre temas como la nutrición, la planificación familiar y los derechos legales. Además, varios miembros del personal periódicamente ofrecen charlas en las clínicas sobre temas como el cuidado del infante, la lactancia materna, y la inmunización.

En el contexto de una sociedad que mantiene límites estrictos sobre el papel social y la mobilidad física de la mayoría de las niñas y mujeres, la BWHC ha adoptado el ambicioso objetivo de habilitar a las mujeres-no obstante sus ingresos o su nivel educacional-para que puedan aprender a manejar su propia salud reproductiva y la salud de sus hijos, de una manera que aumente sus sentidos de competencia y poder personal. 


\section{About the Authors}

Bonnie J. Kay, Ph.D., consultant, is a health systems analyst specializing in issues related to the health of women and their children. Adrienne Germain, Vice President of the International Women's Health Coalition, has worked extensively in Third World countries on women's roles in development, reproductive health and reproductive rights. Maggie Bangser is the Asia Program Officer at the International Women's Health Coalition and has worked on public policy and public interest issues in the United States and the Third World.

The International Women's Health Coalition (IWHC) is an organization dedicated to improving women's reproductive health in the Third World. IWHC serves as a catalyst for change in national and international health and population policies and programs.

\section{Quality/Calidad/Qualité Advisory Committee}

George Brown
Judith Bruce
Ethel Churchill
Francine Coeytaux
Adrienne Germain
Margare+ Homnol
Ann J
Marg
John

Debbie Rogow

Jill Sheffield

Lindsay Stewart

Kerstin 'Trone

Nahid Toubia

rithroutn Vtronintsion

$\begin{array}{ll}\text { HQ } & \text { Kay, Bonnie J. } \\ 766 & \text { The Bangladesh } \\ .033 & \text { women's health } \\ \text { no.3 } & \text { coalition }\end{array}$

\section{POPULATION COUNCIL LIBRARY} NEW YORK

$\begin{array}{ll} & \\ & \\ & \\ \text { Photos: } & \text { John Paul Kay } \\ \text { Typography: } & \text { Village Type \& Graphics } \\ \text { Printing: } & \text { Graphic Impressions }\end{array}$

GAYLORD 3

We invite your comments and your ideas for projects which might be included in future editions of Quality/Calidad/Qualité. If you would like additional copies of this issue or would like to be included on our mailing list, please write to: Ann Leonard, Editor, Quality/Calidad/Qualité. The Population Council, One Dag Hammarskjold Plaza, New York, N.Y. 10017 U.S.A. 